\title{
VOTING RIGHTS, HOME RULE, AND METROPOLITAN GOVERNANCE: THE SECESSION OF STATEN ISLAND AS A CASE STUDY IN THE DILEMMAS OF LOCAL SELF-DETERMINATION
}

\section{Richard Briffault*}

On January 1, 1898, amid fanfare and celebration, the city of Greater New York-“"the greatest experiment in municipal government the world has ever known"l-was born. The consolidation of the cities, counties, and towns on the New York State side of New York Harbor into one great metropolis was a capstone to one century of rapid economic and population growth and a fitting harbinger of a new century of urban greatness for the region and, indeed, the nation. Now, with another century mark approaching, there is a distinct possibility that the City of New York, already beset by a host of economic and social ills, may not make it to its own centennial intact. The New York State legislature has authorized the residents of one of the five boroughs ${ }^{2}-$ Staten Island-to initiate a process of secession and incorporation into a separate city of their own. ${ }^{3}$

The secession of Staten Island has elicited a host of divergent reactions, ranging from the hyperbolic to the humorous. The proponents of secession, seeing themselves currently relegated to a "neo-colonial status" 4 by an inattentive City government, dot their manifestoes with references to the American Revolution, ${ }^{5}$ Lithuania, ${ }^{6}$ the Berlin Wall,

* Professor of Law, Columbia University School of Law. B.A., Columbia, 1974; J.D., Harvard, 1977. Research for this Article was supported by a grant from The Walter E. Meyer Research in Law and Social Problems Fund. I would like to thank Vicki Been, Joel Mintz, Michael Schill, and the participants in the Tulane Law School Faculty Seminar Series on Democratic Responsibility for their thoughtful comments and criticisms.

1. John A. Krout, Framing the Charter, in The Greater City: New York 1898-1948, at 41 (Allan Nevins \& John A. Krout eds., 1948) (quoting editorial of the New York Tribune, January 1, 1898).

2. The City of New York is organized into five boroughs: the Bronx, Brooklyn, Manhattan, Queens and Staten Island. See New York City Admin. Code \& Charter tit. 2, $\S 2-202$ (1991). These correspond to the five New York state counties of Bronx, Kings, New York, Queens and Richmond. At the time of the consolidation of Greater New York, the territory popularly known as Staten Island was incorporated into the City as the borough of Richmond. In 1975, the name was changed to the borough of Staten Island. See New York, Local Laws No. 2 (1975).

3. 1989 N.Y. Laws 3281, ch. 773, as amended by 1990 N.Y. Laws 22 , ch. 17.

4. John J. Marchi, State Senator Disputes Article on Secession, N.Y. L.J., Feb. 13, 1991 , at 2.

5. See Alessandra Stanley, Staten Islanders Brace for Vote on Secession, N.Y. Times, Oct. 26, 1990, at B1, B4 (quoting a Staten Island resident and secession supporter, "It's the same as the Revolution in 1776 . . ..").

6. See Charles Millard, Jr., Baltic Fever: It Can Happen Here, N.Y. Newsday, May 17, 1990, at 74; cf. Staten Island; Free the 380,000, The Economist, Jan. 6, 1990, at 31 
the Iron Curtain, and "the tide of freedom . . rolling across Europe and Asia."7 New York City's Mayor Dinkins has warned of secession as "a step into the night, along a treacherous and foggy path that has never been taken." 8 Many press accounts, by contrast, have found the matter risible, labelling Staten Island's move a "sitcom secession"9 and conjuring up images of Fort Sumter on the Hudson and City troops charging across the Verrazano-Narrows Bridge from Brooklyn ${ }^{10}$ to put down the rebellion of the "Confederate States of New York." 11

The possible secession of Staten Island, while not exactly of the same world-historical dimensions as the dissolution of the Soviet Union into its component republics, is not a laughing matter either. With nearly 380,000 people, ${ }^{12}$ an independent Staten Island would be the second largest city in New York State, ${ }^{13}$ and the 36th largest city in the United States, ${ }^{14}$ with roughly the same population and area as Pittsburgh. ${ }^{15}$ The secession of Staten Island would be the first significant subtraction of territory from a major American city. ${ }^{16}$ At a time of

("The Soviet Union's Baltic republics, it seems, are not the only places where citizens are trying to break away from an overcentralised, over-bureaucratic government.").

7. Letter of State Senator John J. Marchi to Governor Mario Cuomo 2 (Dec. 7, 1989) (on file with the Columbia Law Review).

8. Bob Liff, A Tentative Step Toward SI City; Secession vote likely to pass, but then what?, N.Y. Newsday, Nov. 1, 1990, at 17.

9. Elizabeth Kolbert, Staten Island Is Voting, but It's Only a Sitcom Secession, N.Y. Times, Mar. 11, 1990, § 4, at 22.

10. Liff, supra note 8 , at 17 .

11. Higher Taxes, Naked Statues, Secession Again, Wash. Times, Oct. 26, 1990, at F2.

12. Bureau of the Census, U.S. Dep't of Commerce, 1990 Census of Population and Housing: Summary Population and Housing Characteristics New York 55 (1991) [hereinafter $1990 \mathrm{New}$ York Census Summary] (official Staten Island population is 378,977).

13. Currently, the second largest city in New York State is Buffalo, with an official population of 328,123 . Id. at 7 .

14. According to 1988 Census estimates, Staten Island's population falls between the 35th largest city, Tucson, Arizona, and the 36th largest city, Albuquerque, New Mexico. Bureau of the Census, U.S. Dep't of Commerce, Statistical Abstract of the United States at 34-36 (110th ed. 1990).

15. According to the 1990 Census, Pittsburgh has a population of 369,879 and a land area of 55.6 square miles. Staten Island has about 9,000 more people and three more square miles. Compare Bureau of the Census, U.S. Dep't of Commerce, 1990 Census of Population and Housing: Summary Population and Housing Characteristics, Pennsylvania 526 (1991) with 1990 New York Census Summary, supra note 12, at 364. For a comparison of Staten Island and Pittsburgh, see Graduate School of Political Management, A Study of the Feasibility of an Independent Staten Island 18-19 (1990) [hereinafter Independence Feasibility Study].

16. Detachments of territory from incorporated municipalities, which would include actions by these cities to release the land from municipal control as well as decisions by residents of the territory to leave the municipality, are a standard form of municipal reorganization but are "usually quite small compared to municipal annexations." Joel C. Miller, Municipal Annexation and Border Change, in The Municipal Year Book 1988, at 59, 60 (Int'l City Management Ass'n ed., 1988). From 
widespread and chronic urban stress, the political break-up of the nation's largest city would be of enormous symbolic significance, with implications for the governance of other major urban centers. ${ }^{17}$

For legal scholars, the Staten Island secession raises a number of difficult disputes-disputes that nicely illustrate several dilemmas at the very heart of the notion of local self-government: What is a proper unit of local self-government, and how is that to be determined when two local governments quarrel over the same territory? What is the scope of home rule in the determination of local boundary questions? What is the appropriate structure of governance in metropolitan areas?

This Article explores these issues. Part I traces the historical, political, and legal background to the current Staten Island secession dispute. It gives particular attention to the claim that secession is justified by recent changes in the structure of New York City's government that are said to have altered the terms pursuant to which Staten Island first agreed to join the consolidated City. Parts II and III consider the process of secession. Under legislation adopted by New York State, the power to determine secession has been vested in the people of Staten Island, voting in a referendum, and in the state legislature. The rest of

1980 through 1986 , detachments averaged 29.5 square miles, or about $4.4 \%$ of the land area of annexations during the same period. When measured by population involved, "detachments are even more trivial," averaging about 1,800 persons annually, or less than $1 \%$ of the population of areas annexed. Id.

In recent decades, the most significant detachments have been 15 square miles from Savannah, Georgia (subsequently recaptured by the city), 36 square miles from Mobile, Alabama, and 32 square miles of recently annexed open territory from Oklahoma City, Oklahoma. See Joel C. Miller, Municipal Annexation and Border Change, in The Municipal Year Book 1986 at 72, 78 (Int'l City Management Ass'n ed., 1986) [hereinafter Municipal Yearbook 1986]. The aggregate population of all territories detached from all municipalities nationwide between 1970 and 1985 was 119,000 - or less than one-third of the population of Staten Island. See Joel C. Miller, Municipal Annexation and Border Change, in The Municipal Year Book 1987 at 63, 73 (Int'l City Management Ass'n ed., 1987).

17. Currently, there are active secessionist movements in at least three other large cities: San Francisco, California, Dallas, Texas, and Boston, Massachusetts. See Perry Lang, Bayview Group Proposes Secession From SF; Club Says City Not Spending Enough in Area, San Francisco Chronicle, Oct. 16, 1991, at A15; Elizabeth Hudson, Secession Fever, 87 Years Old, Is on the Rise in Texas Neighborhood, Wash. Post, Nov. 23, 1990, at A3; John Racine, Secession is the Talk of Oak Cliff: Dallas Neighborhood Says it is Being Shortchanged, Bond Buyer, Oct. 9, 1990, at 4; Derrick Z. Jackson, Let Roxbury Study Secession, Boston Globe, Oct. 26, 1990, at 23 (Roxbury secession received more than one-third of votes cast in 1988 referendum).

Moreover, the Staten Island secession legislation has sparked a secession proposal in Queens, New York City's second-largest borough. Maurice Carroll, 'Victimized' Queens Considers Going Solo, N.Y. Newsday, Nov. 19, 1991, at 22; Queen, Civic Leaders Mull Boro Secession Bid, N.Y. Newsday, Queens Ed., Oct. 13, 1991, at 2. In April 1992, the New York Senate passed a bill establishing a secession procedure for Queens that parallels the Staten Island process. See Kevin Sack, State Senate Passes Bill to Allow Queens to Begin Secession Effort, N.Y. Times, Apr. 29, 1992, at B4. 
New York City is entirely locked out of the process. ${ }^{18}$ The City has sought to deploy two legal arguments to pry its way in: (i) that the Fourteenth Amendment's protection of the right to vote prohibits the state from excluding the voters resident in the other four boroughs from voting in the secession referendum; and (ii) that the home rule provision of the New York Constitution limits the state's power to act without the City's consent when, as the City alleges to be the case here, the "property, affairs, or government" of the City are concerned.

As will be seen in Part II, the resolution of the referendum voting question requires a determination of what is the proper unit for local self-determination; yet the voting rights issue has arisen precisely because the proper unit of local self-determination is in dispute. All three parties to the emerging conflict over secession-Staten Islanders, the City of New York, and the State of New York-have sought to wrap themselves in the mantle of local self-determination. Staten Islanders make a political claim to separate municipal existence and to a process in which they may choose independence without the involvement of the rest of the City. The State asserts the power to promote Staten Island's self-government without seeking the City's consent or according its voters a role in the process. The City, in turn, asserts that its selfgovernment is at stake and that the City and its citizens have legal rights to participate in the process that might lead to its break-up. The blessings of local self-government are virtually axiomatic in most contemporary legal scholarship but, as will be seen below, the notion of local selfgovernment provides little guidance for deciding what is the locality in which local self-government is to occur, and how that is to be determined when two local units claim the same territory.

Part III will examine the effect of the state constitutional provision for local home rule ${ }^{19}$ on secession. Like the voting rights issue, the home rule question is in part a dispute over the proper definition of one local unit vis-à-vis another, but home rule raises issues concerning the vertical as well as the horizontal distribution of political power. What is the proper authority of the state legislature with respect to local boundaries? Does the state have the power to break up a city whose home rule is secured by the state constitution in order to promote the autonomy interest of a subunit of that city?

The "state-or-local" question is as knotty as the "which is the proper local unit" question with which it is so closely intertwined. Although state laws on local matters are often portrayed as efforts by a hierarchically superior level of government to arrogate power to itself at the expense of localities, in the case of Staten Island the state is pro-

18. The City's only "participation" is through its representatives in the state legislature.

19. Home rule is the generic term for state constitutional provisions that provide a degree of protection for the structural integrity of local governments and authorize localities to adopt local legislation with respect to local matters. 
moting not its own power but, instead, one local interest against another. The state is arguably transgressing the home rule protection the constitution affords New York City, but it is doing so in order to advance the home rule claim of Staten Islanders. Current home rule doctrine is unable to deal with this secession case. I will propose a procedure for reconciling the competing and legitimate interests of the state, the city, and the secessionist borough.

Finally, Part IV considers the question of secession from the perspective of contemporary debates over the proper political organization of metropolitan areas. At one time, urbanists were dismayed by the extensive fragmentation of most metropolitan areas into dozens, if not scores, of municipalities, ${ }^{20}$ and called for more consolidated areawide governments. ${ }^{21}$ But today many local government scholars praise metropolitan fragmentation on economic and political grounds, contending that it facilitates the accommodation of differences in personal preferences for public goods and services, generates the interlocal competition that promotes governmental efficiency, and preserves opportunities for political participation at the local level. ${ }^{22}$ The implication is that leviathan cities like New York ought to be broken up.

Although the asserted values of interlocal competition and enhanced opportunities for local "voice" in fragmented areas tend to counsel in favor of fragmentation, I will suggest that there are serious countervailing economic, political, and social concerns which make the issue highly uncertain. Ultimately, there may be no neutral, "scientific" answer concerning the optimal structure for metropolitan governance: different structures will favor or harm different interests. ${ }^{23}$

Secession is particularly problematic since it goes beyond the already fragmented metropolitan status quo and breaks up an existing municipality. Even though there is no standard for the optimal size of a municipality or the ideal structure of a metropolitan area, so that the independence of the secessionist subunit might have been appropriate when the municipality was originally formed, a subsequent secession is troublesome because it suggests that different groups and interests in a

20. William A. Fischel, Is Local Government Structure in Urbanized Areas Monopolistic or Competitive?, 34 Nat'l Tax J. 95, 96 (1981) (in 21 of the nation's 25 largest urbanized areas there are 20 or more general purpose local governments; in 12 areas there are more than 50 general purpose local governments; in 6 areas there are more than 100 general purpose local governments).

21. See, e.g., Chamber of Commerce of the United States, Modernizing Local Government 12-13 (1967).

22. See, e.g., Vincent Ostrom et al., Local Government in the United States (1988); Roger B. Parks \& Ronald J. Oakerson, Metropolitan Organization and Governance: A Local Public Economy Approach, 25 Urb. Aff. Q. 18 (1989).

23. Cf. Cass R. Sunstein, Neutrality in Constitutional Law (with Special Reference to Pornography, Abortion, and Surrogacy), 92 Colum. L. Rev. 1, 5-13 (1992) (examining how "neutral" principles frequently precede from, and disguise, a particular baseline distribution of rights and benefits). 
complex urban setting cannot coexist in one democratically governed local unit. A secession may be justified by a showing that the area seeking secession is so exploited by the rest of the City that fairness requires that it be separated from the City, ${ }^{24}$ but a heavy burden of proof ought to be placed on secession's advocates to demonstrate such a case of exploitation. In the absence of such a showing, one hopes that a commitment to the resolution of intralocal conflicts according to democratic processes within a locality will militate against secession.

\section{From Consolidation to Secession}

\section{A. The Process of Consolidation}

The consolidation of Greater New York at the end of the nineteenth century was the culmination of more than a decade of intensive debate, deliberation, legislative lobbying, and political jockeying. The consolidation movement was spearheaded by a coalition of New York civic and mercantile leaders who saw unified municipal control over the territory surrounding New York harbor as essential to the area's continued economic development. Consolidation encountered considerable local opposition, from real estate and taxpayer interests in New York City-at that time, the island of Manhattan and a small piece of what is now the Bronx ${ }^{25}$ - who feared having to bear the costs of physical improvements to the less developed areas proposed for consolidation, and, especially, from many people who lived in Brooklyn, who desired to preserve their city's independence. Moreover, although consolidation won approval of metropolitan area voters in an advisory referendum, the critical political and legal decisions for consolidation were taken by New York's upstate Republican leadership, often over the opposition of New York City's own elected officials. In all this, Staten Island was a minor player ${ }^{26}$-albeit one most enthusiastic for consolidation.

The first serious step toward Greater New York occurred in 1890 when the state legislature passed an act creating "a commission to inquire into the expediency of consolidating the various municipalities in the State of New York occupying the several islands in the harbor of New York." 27 The commission, consisting of members appointed by the governor, the mayors of New York and Brooklyn, and the county

24. See Allen Buchanan, Secession 38-45 (1991).

25. The City of New York first leapt beyond the confines of Manhattan Island in 1874 , with the annexation of three townships in what was then the southwestern corner of Westchester County, but is now a part of the Bronx. See 1873 N.Y. Laws 928, ch. 613.

26. At the time of consolidation, only about two percent of the population of the area that came to be Greater New York resided on Staten Island. See Wallace S. Sayre \& Herbert Kaufman, Governing New York City 18 (1960).

27. 1890 N.Y. Laws \#597, ch. 311 . The broad scope of the proposal reflected the vision of Andrew H. Green, the head of the consolidation movement, who had long 
governments of Westchester, Queens, Kings, and Richmond (Staten Island) promptly and unanimously recommended consolidation, sought to build popular support for the municipal reorganization, and urged the legislature to submit the matter to a referendum. The legislature displayed little urgency over the matter and failed to act on consolidation in 1892 or $1893 .{ }^{28}$ Finally, succumbing to an intensified lobbying effort, the legislature in 1894 voted to submit the matter to an advisory referendum of the electorate in the metropolitan area: "[T]he lobby in favor of the bill had finally convinced the influential leaders at Albany that a popular referendum on the subject was politically harmless." 29

In the 1894 referendum, consolidation squeaked through in Brooklyn-by less than 300 votes out of approximately 129,000 . In the metropolitan area as a whole, the consolidation proposal received fiftyseven percent affirmative support-about the same percentage that it received in Manhattan. Consolidation received its strongest support on Staten Island, where it was approved by seventy percent of the voters. ${ }^{30}$

The referendum, however, did not lead directly to consolidation. Popular opposition in both New York City and Brooklyn seemed to grow after the referendum, and resistance in the legislature stiffened. During the 1895 legislative session, a bill to permit consolidation failed in the Senate by two votes, with every senator from Brooklyn and New York City voting in the negative. ${ }^{31}$

Thereafter the state's Republican leader, "Boss" Platt, came out for consolidation and decided to push it through the 1896 legislature "regardless of opposition." 32 After a considerable effort by Platt and a deal with Tammany Hall, the legislature approved a consolidation bill. At this point, the consolidation process ran into the home rule provision that was a part of the New York Constitution adopted in 1894. Article XII of the new constitution provided for the classification of the cities of the state according to population, declared that any law that related to "a single city, or to less than all the cities in a class" was a "special law," and directed that any special law "relating to the property, affairs, or government of cities" must be sent to the city concerned

insisted on unified government of "our three islands, Manhattan, Long and Staten . . buttresses and breakwaters of a capacious harbor." Krout, supra note 1, at 46 .

28. See David C. Hammack, Power and Society: Greater New York at the Turn of the Century 204 (1982).

29. See Krout, supra note 1 , at 48 .

30. See Hammack, supra note 28 , at 206 . The vote on Staten Island was 5,531 in favor of consolidation and 1,505 opposed. The aggregate vote for all the jurisdictions that became Greater New York was 176,170 in favor and 131,706 opposed. Id.

31. See Krout, supra note 1, at 52. The 1895 legislature did authorize New York to annex additional territory in what was then southern Westchester County, thereby completing the addition to the city of what was later known as the Bronx. 1895 N.Y. Laws 1948, ch. 934.

32. Hammack, supra note 28, at 217. 
for its approval. ${ }^{33}$ If that city rejected the special law, the law would have to be repassed by both houses of the legislature before it could be submitted to the governor for action. ${ }^{34}$

The consolidation bill affected three cities-New York City, Brooklyn, and the then-independent municipality of Long Island City ${ }^{35}$-and was treated as a special law. The bill was submitted to the mayors of the three cities for their review. Although the Mayor of Long Island City approved the measure, the Mayors of both New York and Brooklyn vetoed it. ${ }^{36}$ On legislative reconsideration, the Senate easily repassed the bill, "but then it nearly stuck in the assembly."37 Tammany, which had supported the bill on its initial passage, bolted, and many Brooklyn and upstate Republicans resisted. "Twisting arms and making free use of political threats and promises, Platt forced the measure through." 38 The Republican leader made the consolidation bill a test of Republican Party loyalty; even so, "it required all Senator Platt's energy, and the full weight of his influence throughout the state, to secure a constitutional majority." 39 On May 11, 1896, Governor Morton signed the bill into law.

As enacted, the consolidation measure was silent as to the form of the new city's government. It simply provided that the consolidated city would come into existence on January 1,1898 , and created a commission to write a charter. The legislature adopted the commission's proposed charter in early 1897 . Under the home rule article, the charter bill was submitted to the mayors of the affected cities for approval. Although this time the Mayor of Brooklyn approved, the Mayor of New York once again exercised his veto. The legislature, however, easily repassed the measure, providing the new city with a charter in time for its birth. ${ }^{40}$

\section{B. The Morris Litigation and the Secession Legislation}

Following consolidation, Staten Island "embarked upon a new, fresh phase of prosperous and satisfactory development."41 "[C]onsiderable work was done on the Island's roads," a high school was built, the water supply improved, and a municipal ferry link to Manhattan provided by the City. ${ }^{42}$ Staten Island's population more

33. N.Y. Const. of 1894 , art. XII, $\S 2$. There were three population classes for cities: cities of 250,000 or more; cities of 50,000 to 200,000 ; and all others.

34. See id.

35. Long Island City is currently a neighborhood in the borough of Queens.

36. See Hammack, supra note 28 , at 222.

37. Id.

38. Id.

39. Id. In the final roll call only 6 of the 114 Republicans in the Assembly and only 1 of the 36 Republicans in the Senate voted in the negative. Krout, supra note 1, at 56 . 40. See id. at 59 .

41. Henry G. Steinmeyer, Staten Island 1524-1898, at 99 (rev. ed. 1987).

42. See id. at 98 . The City took over the ferry from a private line in 1905 and put 
than doubled from 67,000 to 138,000 in the first quarter of the new century,43 and it enjoyed a second major spurt of growth after the Verazzano-Narrows Bridge opened in 1964 to provide the first surface link between the island and the rest of the City. ${ }^{44}$ Despite these developments as well as their initial high level of support for consolidation, Staten Islanders occasionally displayed ambivalence about their affiliation with the rest of the City. Complaints about the City's lack of attention to the "forgotten borough" 45 and inadequate investment in local development alternated with concerns about excessive growth, demographic change, and loss of the Island's suburban charm. Short-lived secessionist impulses crystallized around various City plans to site undesirable sanitation facilities on the Island and over a proposed mixedincome urban renewal program. ${ }^{46}$ These disputes were resolved through the City's cancellation of the proposals that had provoked the secessionist talk. A serious secessionist movement, however, emerged in response to the decision of the United States Court of Appeals for the Second Circuit in 1983 that the City's Board of Estimate was subject to the strictures of the "one person, one vote" doctrine. ${ }^{47}$

At the time of the litigation and for most of New York's twentieth century history, the Board of Estimate wielded broad authority over the City's land use and zoning process, the disposition of City property, and the grant of contracts and franchises, and it shared power with the City Council over the budget. The Board consisted of eight members: three officials elected on a city-wide basis (the mayor, the comptroller, and the City Council president) who, at the time of the litigation, cast two votes apiece, and the five borough presidents, who each cast one vote. ${ }^{48}$ Given the wide disparity in population among the five boroughs-with Brooklyn, the largest borough, having more than six times the population of Staten Island, the smallest-the Board had long been an inviting target for a "one person, one vote" challenge. State and lower federal courts had previously dismissed "one person, one vote" claims, finding that the Board was not subject to the constitutional vot-

five modern boats into service. Staten Island was connected to the City's Catskill Water Supply in 1917. See id. at 116.

43. See id.

44. Michael N. Danielson \& Jameson W. Doig, New York: The Politics of Urban Regional Development 203 (1982) (Staten Island population increased by $30 \%$ in the six years following the opening of the Bridge).

45. Howard Kurtz, A Low-Profile Borough's High-Stakes Case for Secession, Wash. Post, Feb. 9, 1988, at A3.

46. See James M. Bohanek, Jr., Staten Island, New York: The Rebellious Borough 10-20, 46-50 (discussing secessionist movements of 1916, 1938, and 1947, which were responses to City plans for a garbage reduction plant or a garbage dump on Staten Island, and the secessionist proposal of 1966, provoked by a City plan for urban renewal housing in South Richmond) (on file with the Columbia Law Review).

47. See Morris v. Board of Estimate, 707 F.2d 686 (2d Cir. 1983).

48. See id. at $687-88$. 
ing rule because it lacked general legislative authority ${ }^{49}$ and because its members were not elected to the Board, but rather served by virtue of their election to other posts. ${ }^{50}$

In Morris v. Board of Estimate, ${ }^{51}$ the Second Circuit rejected these arguments and found the Board to be an elective body with broad governmental authority, and therefore subject to "one person, one vote." Although the Court remanded for a determination of how much inequality existed given the Board's unusual mix of city-wide and borough representatives, and for consideration of whether the City could justify the deviations from equality that resulted, the 1983 decision was the beginning of the end for the Board. ${ }^{52}$

The Board's death knell sounded particularly ominous on Staten Island, which had been the greatest beneficiary of the "one borough, one vote" rule. ${ }^{53}$ Some Staten Islanders had long felt that their borough was short-changed by the City's administration, ${ }^{54}$ and that the City treated the Island as a dumping ground for the City's undesirable facilities. ${ }^{55}$ The further loss of political clout threatened to turn an already unpleasant situation into an intolerable one. The Borough President announced that if the Board of Estimate were ultimately held to be unconstitutional, he would have to consider secession; and the borough's senior political figure, State Senator John Marchi, issued a report justifying secession as an alternative to remaining in a City without equal borough representation on the Board of Estimate. ${ }^{56}$

The secession issue remained relatively quiescent as the Morris litigation continued to wend its way through the federal courts, but be-

49. See, e.g., Bergerman v. Lindsay, 255 N.E.2d 142, 146 (N.Y. Ct. App. 1969), cert. denied, 398 U.S. 955 (1970).

50. See, e.g., Morris v. Board of Estimate, 551 F. Supp. 652, 656 (E.D.N.Y. 1982).

51. 707 F.2d 686, 690 (2d Cir. 1983).

52. On remand, the district court determined that equal voting strength for each borough president, despite the differences in borough population, resulted in a deviation from equality of $132.9 \%$ between the smallest and largest borough, see Morris v. Board of Estimate, 592 F. Supp. 1462, 1470 (E.D.N.Y. 1984), and that this deviation was not justified by any of the political or historical reasons the City presented in support of the principle of borough equality, see Morris v. Board of Estimate, $647 \mathrm{~F}$. Supp. 1463, 1408-75 (E.D.N.Y. 1986). These rulings were affirmed by the Second Circuit. See Morris v. Board of Estimate, 831 F.2d 384, 393 (2d Cir. 1987).

53. Only one other borough, the Bronx, has a population below the borough mean, and its deviation from the mean is relatively slight. See Morris v. Board of Estimate, 592 F. Supp. 1462, 1475 (E.D.N.Y. 1984).

54. See, e.g., Remedies of a Proud Outcast: The Legal Probability and Implications of Restructuring the Government and Boundaries of the City of New York, A Staff Report to the Chairman of the New York Senate Finance Committee 1-2 (July 1983) [hereinafter Remedies of a Proud Outcast].

55. Staten Island literally is the City's "dumping ground": it is the site of Fresh Kills, the landfill that receives most of the City's solid waste. According to one study, of the 5.2 million tons of garbage deposited there each year only 371,000 are generated on Staten Island itself. Independence Feasibility Study, supra note 15, at 14.

56. See Remedies of a Proud Outcast, supra note 54, at 26. 
came reanimated in March of 1989, when the Supreme Court affirmed the Second Circuit's 1987 determination that the "one borough, one vote" rule was unconstitutional. ${ }^{57}$ The Morris decision, and the subsequent action of New York City's Charter Revision Commission to abolish the Board and redistribute its powers, caused deep dismay on Staten Island. The Island's Democratic Borough President, in a difficult reelection battle, came out for secession, and Senator Marchi, a Republican and an important member of the State Senate's leadership, persuaded the Senate to consider his bill authorizing secession. Whether out of deference to a senior leader, or on the assumption that the measure would die in the Democratic-controlled Assembly-or both-secession sailed through the Senate by a vote of 58 to 1 .

In the Assembly, the Democratic members from Staten Island importuned the Democratic leadership to allow the measure to be taken up. They argued that their local political futures depended on being able to say they had taken a strong stand for secession. ${ }^{58}$ The Assembly's Democratic leadership, sensitive to the needs of fellow Democrats from Staten Island and apparently assuming they could count on the Governor to veto the measure, placed the secession bill on the agenda. ${ }^{59}$ The bill passed the Assembly by a vote of 117 to 21 . That few who voted for the bill thought it would become law may be illustrated by the fact that 32 out of 51 Assemblymembers from the other four boroughs of New York City voted in favor of the secession bill. ${ }^{60}$ The Governor, however, signed the bill.

As passed by the legislature, Senator Marchi's bill provided for submission to the voters of Staten Island the question: "Shall the borough of Staten Island separate from the city of New York to become the city of Staten Island?" In the event of an affirmative vote, the bill provided for the creation of a commission, appointed by Staten Islanders and senior state officials and consisting entirely of Staten Island residents, ${ }^{61}$ to draft a charter for Staten Island for submission to the Staten Island electorate. ${ }^{62}$ If the Staten Island voters approved the charter, Staten Island would then become independent, with the charter as its

57. Board of Estimate v. Morris, 489 U.S. 688 (1989), aff'g 831 F.2d 384 (2d Cir. 1987).

58. See Kolbert, supra note $9, \S 4$, at 22 .

59. Id.

60. See Defendant's Memorandum of Law on Summary Judgment Motion at 6-7, City of New York v. State, 556 N.Y.S.2d 823 (Sup. Ct. 1990) (No. 46770/89).

61. The Commission consists of the members of the state legislature representing Staten Island and additional members appointed separately by the Governor, the temporary President of the Senate, the Speaker of the Assembly, and the legislators representing Staten Island. All appointed Commission members must be Staten Island residents. 1989 N.Y. Laws 2356 , ch. $773 \S 4$ (a).

62. The bill provided for the submission of the proposed charter to the Governor, the leaders of the state legislature, and the Staten Island Borough President, but did not condition the effectiveness of the charter or of secession on the approval of any of these officials. Id. at $\S 4$ (c). 
governing instrument. ${ }^{63}$

In his memorandum approving the bill, and in other public commentary, Governor Cuomo chose to characterize the bill as primarily an opportunity for the voters of Staten Island to consider secession, not as a measure leading ineluctably to separation from New York City. ${ }^{64}$ Moreover, the Governor linked his approval of the secession referendum bill to the adoption of supplemental legislation that required state legislative approval of secession and of the proposed Staten Island charter before either could become effective. After considerable behind-the-scenes bargaining, and in the face of growing New York City opposition, this amendment passed, by a substantial 51 to 6 margin in the Senate and an only slightly narrower 94 to 36 vote in the Assembly. ${ }^{65}$

Under the bill as amended, the procedure for secession comprises the following:

an initial referendum to be held in 1990 to determine whether the voters of Staten Island wish to create a charter commission to provide for the separation of the borough from the City of New York and to establish an independent city;

if the referendum question passes, appointment of a Staten Island Charter Commission;

a two to two-and-one-half year process of Commission deliberation and preparation of a charter;

a referendum of the voters of Staten Island on the proposed charter;

if the proposed charter wins referendum approval, legislative determination of whether to adopt legislation "enabling the borough of Staten Island to disengage and separate from the city of New York."

Upon adoption of the enabling legislation, Staten Island would become an independent city under its own charter. ${ }^{66}$

Although the Governor characterized the amendment to the secession law as appropriate "to meet the unarguably desirable objective of involvement by the whole state through its elected representatives," more cynical observers labelled the amendment "lawsuit insurance" designed to shield the secession procedure from New York City's claim that it violated the home rule provision of the state constitution without

63. The secession measure also provided that if the charter failed to win voter approval, the Charter Commission could be given the opportunity to prepare and submit a second charter for voter consideration. Id. at $\S 4(e)$.

64. See Executive Memorandum approving L. 1989, ch. 773, Dec. 15, 1989, Session Laws of New York 2438 (McKinney's 1989); Governor Mario Cuomo, Letter to the Editor, N.Y. Times, Jan. 2, 1990, at A18.

65. This time the assemblymembers from the other four boroughs voted against the measure, 35 to 15. See Affidavit of Joel Berger at Exhibit A, City of New York v. State, 556 N.Y.S.2d 823 (Sup. Ct. 1990) (No. 46770/89).

66. 1990 N.Y. Laws 35-36, ch. $17 \S 3$. 
actually giving the City any formal role in the process. ${ }^{67}$

The City of New York attempted, without success, to block the 1990 referendum. Both the trial court that first heard the City's case and the intermediate appellate court firmly rejected the City's position that all City voters had a right to participate in the referendum and that the secession legislation violated the home rule provisions of the state constitution because the consent of the City had not been sought. Both courts ruled broadly that the local boundary questions underlying the two legal issues fell within the plenary authority of the legislature to resolve. 68

The state's highest court, the Court of Appeals, affirmed the lower court rulings and authorized the referendum to go forward, but it did so on narrow grounds that left open the constitutionality of a final decision by the legislature to separate Staten Island from New York City without the City's consent. In City of New York v. State of New York (the Secession Referendum case) ${ }^{69}$ the Court of Appeals emphasized that the initial secession referendum would not decide the secession question or commit the state to support secession. Since its outcome would have no "direct effect" on the City of New York, home rule was not implicated. ${ }^{70}$ Nor did the limitation of the referendum electorate to Staten Island residents infringe the voting rights of other New Yorkers, since in the court's view, the referendum was simply intended "to allow Staten Island voters to express their views as to whether, and how, they might wish to separate from New York City-while affording them no unilateral right to do so."71 Two members of the court dissented on home rule grounds.

The referendum on whether to create a charter commission and initiate the secession process was held in November 1990, and Staten Islanders voted in the affirmative by a margin of eighty-two percent to eighteen percent. ${ }^{72}$

67. See Elaine Rivera, Bill Passed Letting State, Not City, OK SI Secession, Newsday, Mar. 1, 1990, at 18. According to Assemblywoman Elizabeth Connelly, "the bill still allows the people of Staten Island to decide their own destiny. And hopefully this will address the lawsuit." Id. Accord Victor A. Kovner, Staten Island Secession, N.Y. L.J., Apr. 17, 1991, at 2 (New York City corporation counsel contends that the governor's counsel sought immediate passage of the amendment to the secession law "because the city might prevail in its lawsuit if there were no amendment").

68. See City of New York v. State, 557 N.Y.S.2d 914, 917 (App. Div.), aff'g 556 N.Y.S.2d 823, 827 (Sup. Ct. 1990).

69. 562 N.E.2d 118, 120 (N.Y. 1990).

70. See id. at 120 .

71. Id. at 121.

72. See Alessandra Stanley, Secession; Staten Island Votes a Resounding Yes on Taking Step Toward Separation, N.Y. Times, Nov. 7, 1990, at B7 (with 94\% of precincts reporting). Voter turnout on Staten Island for the 1990 general election was only $44 \%$, but that was a significantly higher turnout than in the other four boroughs. See Maurice Carroll, Desperately Seeking Lost Voters, N.Y. Newsday, Nov. 27, 1990, at 19. 


\section{Was the Board of Estimate "Part of the Deal" for Consolidation?}

As Governor Cuomo noted in his approval message, the secession movement is fueled by a "long list of grievances by the people of Staten Island over the years," and by a sense of Staten Island's differences from the rest of the City. But the catalyst for secession was the demise of the Board of Estimate, with its "one borough, one vote" rule, and the concomitant reduction of Staten Island's power in the City's governing structure. For some proponents of secession and their sympathizers, the abolition of the Board was not simply a loss of power but an alteration of the very basis upon which Staten Island had entered Greater New York. ${ }^{73}$

This sense of the betrayal of the terms of an original consolidation agreement, captured by Governor Cuomo's phrase, as reported in the newspapers, that the Board of Estimate was "part of the deal"74 for consolidation, has added an extra degree of aggrieved legitimacy to what otherwise might be seen as a parochial desire for Staten Islanders to separate from New York City and its problems.

Indeed, political theorists who have studied secession in the international setting have urged that "a sound justification for secession must include a justification for taking the seceding territory." 75 Secession involves more than just the decision by a group of people, dissatisfied with their government, to leave the jurisdiction. In a secession, people are determined to leave the jurisdiction and to take their territory with them. ${ }^{76}$ To provide an argument for secession with some legitimacy, secessionists must have "a normatively sound claim to territory."77 Most commonly, this will entail a "historical grievance," such as the claim that the territory was wrongfully or unjustly seized by the jurisdiction that currently controls it. ${ }^{78}$ The secession of the Baltic States from the Soviet Union is, perhaps, the clearest modern example

73. See, e.g., Letter of Edward J. Maloy III, Chairman of the Board of the Staten Island Chamber of Commerce, to Governor Mario Cuomo, Dec. 9, 1989 (justifying consideration of secession "since the status which was negotiated upon affiliation has been involuntarily terminated" by the elimination of Board of Estimate) (on file with the Columbia Law Review).

74. Quoted in Bob Liff, Road to Secession Would Not be Made Easy for SI, Guv Says, Newsday, Oct. 26, 1990, at 18; Liff, supra note 8, at 17.

75. Buchanan, supra note 24 , at 68 .

76. See id. at 10-11 (comparing emigration with secession). Also, secession differs from revolution in that it does not seek to overthrow an existing government or make fundamental changes in the existing state. Instead, secessionists seek "to restrict the jurisdiction of the state in question so as not to include" the secessionists and the territory they occupy. Id. at 10.

77. Lea Brilmayer, Secession and Self-Determination: A Territorial Interpretation, 16 Yale J. Int'l L. 177, 192 (1991).

78. See Buchanan, supra note 24 , at $67-70$; Brilmayer, supra note 77 , at $189-91$; Cass R. Sunstein, Constitutionalism and Secession, 58 U. Chi. L. Rev. 633, 661-63 (1991). 
of secession as the rectification of a prior wrongful acquisition of territory.

In the case of Staten Island, secessionists do not claim that the original consolidation of Staten Island into Greater New York was an unjust conquest when it occurred. The argument is, instead, that Staten Island's consent to consolidation was premised on a commitment to borough equality in the City's structure of governance. In other words, the "one borough, one vote" rule on the Board of Estimate, or something very much like it, was a "part of the deal" by which Staten Island agreed to come into the City.

The "part of the deal" argument, however, is historically flawed in two ways: there was no "deal," and the Board of Estimate was not "part" of the original consolidation.

The notion of a "deal" suggests that consolidation was the result of a consensual process, the voluntary coming together of the cities, counties, and towns surrounding New York harbor on mutually-agreedupon terms, in particular, the Board of Estimate. ${ }^{79}$ But that was not the case. As my brief history of the consolidation process indicates, Greater New York was put together in Albany by state politicians. Although Staten Island and other metropolitan area voters had supported consolidation in a referendum, that referendum was advisory, without legally binding effect. Indeed, as the travails of the consolidation proposal in the 1895 and 1896 legislative sessions indicate, the referendum had little immediate precatory effect either. Consolidation was imposed over the opposition of the Mayors of New York and Brooklyn and of most of the state legislators elected from those two cities. There was certainly no "deal" involving the communities that became the five boroughs. With the exception of the tiny municipality of Long Island City, it is difficult to say that any local government that became a part of Greater New York actually "consented" to consolidation. ${ }^{80}$

Nor was the Board of Estimate-or the principle of borough equality-part of consolidation. When Staten Island voters and other metropolitan area residents voted on the idea of consolidation in 1894 , there was no charter before them. Similarly, in 1896, the state legislature imposed consolidation without establishing a structure for the new

79. As the Chairman of the Board of the Staten Island Chamber of Commerce put it, "Staten Island took voluntary legislative action to accomplish its affiliation with the City of New York and did so only after ensuring that its voice would not be muffled by the more populous boroughs by advocating for the creation of the Board of Estimate." Malloy, supra note 73 .

80. Cf. Gregory Craven, Secession: The Ultimate States Right 74-81 (1986) (discussing and rejecting argument that Australian states enjoy a right of secession from Australian federation because British Parliament's adoption of the act creating the federation followed Australian voters' approval of the federation in a referendum; the popular vote, even though a factual predicate to federation, "was legally a mere antecedent historical circumstance"). 
city's government. When a charter was approved in 1897, it contained nothing like the Board of Estimate of the 1980s or the principle of borough equality. 81

The first charter for consolidated Greater New York vested all legislative power and final budget authority in a bicameral Municipal Assembly. The smaller house, the City Council, had twenty-nine members, of whom two were to come from Staten Island;82 in the larger house, the Board of Aldermen, Staten Island would get one out of sixty seats. ${ }^{83}$ With three seats in the fifty-one-member City Council of 1992, Staten Island is certainly not getting less representation than it did in 1898.

The 1897 Charter did preserve New York's Board of Estimate and Apportionment, which had been created in the unconsolidated city in 1873 to manage the budget. But the Board had no borough representatives, and was instead dominated by the mayor and his appointees. ${ }^{84}$ The only role for borough representatives at the city-wide level was on the Board of Public Improvements, which was created to regulate capital expenditures. Borough presidents sat on this Board, but they could vote on only those matters that concerned their own boroughs, thus assuring that the Board of Public Improvements would be dominated by the city-wide members. ${ }^{85}$ Within their own boroughs the borough presidents had relatively little power beyond making recommendations to the Municipal Assembly and the Board of Public Improvements for the undertaking of improvements and the regulation of nuisances, disorderly houses, and saloons. ${ }^{86}$

The modern Board of Estimate did not emerge until a charter revision in 1901, which abolished the City Council and vested both the Council's budgetary authority and the functions of the Board of Public Improvements in the Board of Estimate. The 1901 Charter altered the Board's membership to include the mayor, the comptroller, the president of the Board of Aldermen, and the five borough presidents. Even then, the Charter did not embrace the principle of borough equality:

81. See 1897 N.Y. Laws, ch. 378 (bound separately).

82. See 1897 N.Y. Laws, ch. $378 \S \S 18-19$ (bound separately). The Council consisted of a president, elected city-wide, and 28 members elected from 10 districts. Manhattan was given 12 members; Brooklyn, 9; the Bronx 3; Queens 2, and Staten Island 2. See id. § 19.

83. See 1897 N.Y. Laws, ch. $378 \S 24$ (bound separately). The Board of Aldermen were elected from the state assembly districts within New York City.

84. The Board had 5 members: the mayor; the independently elected comptroller; the independently elected president of the Board of Aldermen; and two mayoral appointees-the president of the Department of Taxes and Assessment, and the corporation counsel. See 1897 N.Y. Laws, ch. $378 \S 226$ (bound separately).

85. The Board consisted of the mayor, the comptroller, the corporation counsel, the Board's president, six other city commissioners-all mayoral appointees-and the five borough presidents. See 1897 Laws, ch. $378 § 410$ (bound separately).

86. See 1897 N.Y. Laws, ch. $378 \S 393$ (bound separately). 
the Borough Presidents of Manhattan and Brooklyn, the two most populous boroughs, each had two votes, while the other three borough presidents were given one vote apiece. ${ }^{87}$ Borough equality did not arrive at the Board of Estimate until 1958, when the presidents of all five boroughs were first given an equal number of votes. ${ }^{88}$

Thus, neither the Board of Estimate nor the principle of borough equality were part of the structure of the City's governance at the time of consolidation. The Morris decision and the 1989 New York City Charter revision ${ }^{89}$ did not undo any agreement which was the predicate for Staten Island's consolidation into New York City.

To be sure, the Staten Islanders' case for secession has not been premised solely on this historical claim. As Governor Cuomo's approval message indicates, current grievances and the "relatively small participation" of Staten Island in the City's governance following the demise of the Board of Estimate are important motivating concerns. Indeed, the Governor in his formal statements has refrained from any reference to a historical basis for secession.

Nor do Staten Islanders need to establish a historical claim to their territory. They have not claimed a legal right of secession that might be sustained even in the face of state opposition, but rather have advanced a political argument to the legislature that they ought to be allowed to secede. The legal rights formally at stake in this secession are those of the State of New York, which asserts the power to separate Staten Island from New York City without the City's participation or consent, and the City of New York, which denies that the State has that power. This dispute between the State and City is the focus of the next two Parts.

\section{The Federal Constitution and Local Secession}

\section{A. The Right to Vote and Secession Referenda}

The principal federal constitutional question raised by a local secession is the right to vote in secession referenda. ${ }^{90}$ The State of New

87. In 1900, Manhattan had a population of $1,850,000$; Brooklyn, 1,167,000; the Bronx, 201,000; Queens, 153,000; and Staten Island, 67,000. See Sayre \& Kaufman, supra note 26 , at 18 .

On the Board of Estimate, the three city-wide officials were given three votes apiece, thus assuring they could outvote the borough presidents. This guarantee that the citywide officials could outvote the borough presidents remained a constant of the Board's voting structure through subsequent charter revisions. See R. Alta Charo, Designing Mathematical Models to Describe One-Person, One-Vote Compliance by Unique Governmental Structures: The Case of the New York City Board of Estimate, 53 Fordham L. Rev. 735, 743-44 (1985).

88. See 1958 N.Y. Laws 1571 , ch. 719. In 1957, the borough populations were: Brooklyn, 2,602,000; Manhattan, 1,794,000; Queens, 1,763,000; Bronx, 1,424,000; and Staten Island, 212,000. See Sayre \& Kaufman, supra note 26, at 18.

89. See Charter of the City of New York, ch. $8 \S \S 203-204$.

90. Apart from the constitutional and statutory protections of voting rights and the 
York has limited participation in the two popular votes on secessionthe referendum that initiated the process in 1990 and the future referendum on independence and a charter for Staten Island-to the residents of Staten Island. In the words of Governor Cuomo, "Staten Island has the right to start it, and Staten Island has the right to finish it."91 According to the Governor, the secession debate would be a "grand new experience" for Staten Islanders and a "golden moment" for the democratic determination of their collective future. ${ }^{92}$ The secession of Staten Island would also affect the collective future of the residents of the other four boroughs, however, and they are being left out of the process.

One method of inserting these other New Yorkers into the secession debate is by way of the Fourteenth Amendment's protection of the right to vote. As the Supreme Court has recognized, ${ }^{93}$ the vote enables people to voice their concerns, protect their interests, and participate in the determination of political issues that affect them and their community. ${ }^{94}$ The equal distribution of the franchise is a symbolic statement of the equal political value of all citizens, much as the denial of the vote or the provision of an unequally weighted vote denigrates the political status of the disenfranchised. In a succession of cases in the 1960s and early 1970s, the Court determined that when a state decided to select public officials or make public decisions by popular election, a restriction on the right to vote would be subject to "exacting judicial scru-

general prohibition on racially invidious legislation, see, e.g., Gomillion v. Lightfoot, 364 U.S. 339, 349 (1960) (Whittaker, J., concurring) (basing invalidation of state's racially motivated redrawing of municipal boundaries on equal protection clause of Fourteenth Amendment, rather than Fifteenth Amendment's ban on race-based restrictions of right to vote), neither New York City nor its residents would appear to have any basis for a federal constitutional challenge to state legislation authorizing the secession. Generally, local governments have no federal constitutional rights against their states, and local residents have no constitutional claim to belong to a particular local government. See Richard Briffault, Our Localism: Part I-The Structure of Local Government Law, 90 Colum. L. Rev. 1, 7 \& nn.7-9 (1990) [hereinafter Our Localism I].

Federal constitutional concerns could be triggered by other aspects of secession, such as whether the state's allocation of New York City's debts impairs the security of New York City's bondholders in violation of the Contracts Clause, or whether the disposition of the City's property on Staten Island implicates the Takings Clause. See infra note 259. But Contracts and Takings Clause arguments would not affect the authority of a state to break up a city or the process the state may utilize in doing so.

91. Bob Liff, Cuomo Signs Secession Bill; Action opposed by Dinkins, SI President, Newsday, Mar. 2, 1990, at 19.

92. Id.

93. See, e.g., Reynolds v. Sims, 377 U.S. 533, 555-56 (1964).

94. Professor Michelman finds that "[a] person may value enfranchisement in political affairs . . . for either of two types of reasons distinguishable as 'instrumental' and "constitutive." "The instrumental value of voting is "to defend or further interests formed and defined outside of politics." The constitutive value is the experence of political engagement itself. Frank I. Michelman, Conceptions of Democracy in American Constitutional Argument: Voting Rights, 41 Fla. L. Rev. 443, 451 (1989). 
tiny" and would need to be closely tailored to meet a compelling state need to survive this scrutiny. ${ }^{95}$

Modern voting jurisprudence is most clearly exemplified by Kramer v. Union Free School District No. 15,96 in which the Supreme Court invalidated a New York law that limited the right to vote in certain school board elections to owners or renters of property in the school districtthat is, to direct and indirect payers of the local property tax that funded the school district-and to parents. The state argued that it could so limit the franchise because parents and direct and indirect property taxpayers constituted the members of the community "primarily interested" in or "primarily affected" by school affairs. The Court found, however, that since other residents of the district were also "interested in and affected by school board decisions," the state's limitation on the electorate did not meet "the exacting standard of precision we require of statutes which selectively distribute the franchise." 97

If taken to its logical conclusion, such an "all-interested" or "allaffected" standard ${ }^{98}$ would ultimately be destructive of the system of territorially-based local governments. Local government actions frequently have extralocal effects, and nonresidents may be very interested in the decisions of a particular locality. New Jersey residents who commute to jobs in New York are affected by and interested in New York's political and fiscal decisions, just as New Yorkers who live downwind from New Jersey factories or waste disposal sites are affected by and interested in the land use and zoning decisions of New Jersey municipalities. An all-affected standard would leave the size of local electorates indeterminate and potentially variable from issue to issue, ${ }^{99}$ and would erode the connection between a particular community and its representatives. The Supreme Court has recognized these dangers and has determined that the protection of the right to vote on an equal basis only extends within a political jurisdiction. Bona fide residency requirements can withstand the strict judicial scrutiny applied to limitations on the franchise because they are "necessary to preserve the basic conception of a political community." 100

95. See Dunn v. Blumstein, 405 U.S. 330, 335 (1972); City of Phoenix v. Kolodziejski, 399 U.S. 204, 209 (1970); Hadley v. Junior College Dist., 397 U.S. 50, 54-55 (1970); Cipriano v. City of Houma, 395 U.S. 701, 704 (i969); Kramer v. Union Free School Dist. No. 15, 395 U.S. 621, 621-28 (1969).

96. 395 U.S. 621 (1969).

97. Id. at $632 \&$ n. 15.

98. See, e.g., Robert A. Dahl, After the Revolution? Authority in a Good Society 64 (1970) ("Everyone who is affected by the decisions of a government should have the right to participate in that government.").

99. See Frederick G. Whalen, Prologue: Democratic Theory and the Boundary Problem, in Liberal Democracy: NOMOS XXV 13, 19 (J. Roland Pennock \& John W. Chapman eds., 1983).

100. Dunn v. Blumstein, 405 U.S. 330, 343-44 (1972). 


\section{B. The Question of Boundaries}

Equal protection of the right to vote, thus, only operates within jurisdictional borders. The problem with the secession referenda is that the state has created two relevant jurisdictions: the Borough of Staten Island and the City of New York. If Staten Island is the relevant political community for decisions concerning the independence and charter of the new city, then the state has precisely mapped the electorate on the proper jurisdiction. Secession, however, would also involve the subtraction of almost 400,000 people, one-fifth of the land area, and significant public infrastructure and tax base from New York City. The relevant jurisdiction, then, could easily be the entire City, and the State's exclusion of the qualified voters from the other four boroughs would be subject to strict scrutiny. Even if one believed that Staten Islanders are more interested in the secession issue and more directly affected by its outcome than are other New Yorkers, Kramer suggests that if New York City were deemed to be the relevant jurisdiction the state would have a difficult time demonstrating that Staten Islanders are so much more interested in and affected by secession that limiting the referendum electorate to them would satisfy the requirement of a precise alignment of the franchise with "interested" or "affected" residents. Thus, whether Staten Island or New York City is the relevant jurisdiction is crucial for the application of the Kramer analysis.

Two Supreme Court cases suggest that where two local boundaries may each be used to delimit the electorate for purposes of the application of Equal Protection analysis, the state will be given considerable discretion in determining which boundary counts even when it operates to deny some group of affected residents an equally weighted vote, or any vote at all.

In Town of Lockport v. Citizens for Community Action at the Local Level, Inc. ${ }^{101}$ the Court considered a challenge to the New York State procedure that enables a county to switch from a traditional "weak county" government to a "strong county" format, with a new administrative structure and enhanced regulatory capacity. Such a change requires the approval in a referendum of concurrent majorities of voters who live in cities and of those who live outside the cities. A proposed strong county charter for Niagara County twice won the approval of city voters and of a majority of all county voters, but both times was rejected by a majority of the noncity voters and thus failed. The city voters contended that the concurrent majority requirement violated the Equal Protection Clause. The Supreme Court, however, unanimously disagreed.

The Lockport Court likened the county reorganization, which strengthened the county government and weakened other local units,

101. 430 U.S. 259 (1977). 
to "the structural decision to annex or consolidate."102 A decision to adopt the "strong county" form of government, like an annexation or a consolidation, could have a differential impact on the "separate and potentially opposing interests" of city and noncity voters within the county. ${ }^{103}$ The Court assumed that in an annexation proceeding, the state could recognize that the residents of the annexing city and the area to be annexed formed different constituencies with different interests since " $[t]$ he fact of impending union alone would not so merge them into one community of interest as constitutionally to require that their votes be aggregated in any referendum." 104 Thus, New York State could require the concurrent approval of the charter change by different groups of county voters.

Lockport's analogy of the county charter vote to an "impending union" or a "proposal . . to form a consolidated unit" 105 is striking, since the city and noncity portions of Niagara County had been united in a single county unit since the beginning of the nineteenth century. The county charter vote was not an annexation or consolidation. New territory was not being added to Niagara County; outsiders were not being subjected to the county's authority. Instead, the county was simply considering an internal reorganization.

Lockport's differentiation of city and noncity voters did not follow automatically from the Court's traditional respect for residency requirements. Indeed, in the case that first extended the "one person, one vote" doctrine to the local level, the Court treated the unit of residency for county elections as the county as a whole, rejecting the contention that the different interests urban and rural voters have in county government could justify giving the latter a greater say in county elections. ${ }^{106}$ Moreover, Lockport cannot be read simply as authorizing a supermajority requirement for a decision that has extraordinary significance for a polity. The Court had previously sustained supermajority requirements, but only on condition that the supermajority rule not privilege a particular group because of "group characteristics" such as "geographic location." 107 The concurrent majority requirement in Lockport, however, turned precisely on geographic location. ${ }^{108}$

102. Id. at 271-73.

103. Id. at 271-72.

104. Id. at 271 .

105. Id.

106. See Avery v. Midland County, 390 U.S. 474, 483-84 (1968).

107. Gordon v. Lance, 403 U.S. 1, 4 (1971) (sustaining $60 \%$ voter approval requirement as precondition for issuance of bonded indebtedness).

108. Lockport's analysis also focused in part on the fact that the election in question was a " 'single-shot' referendum." Town of Lockport v. Citizens for Community Action at the Local Level, Inc., 430 U.S. 259, 266 (1977). In a referendum, unlike the election of legislators, "the expression of voter will is direct, and there is no need to assure that the voters' views will be adequately represented through their representatives in the 
The Court's deference to the state's power to determine the territorial scope of the right to vote in elections involving local boundaries was broadened in Holt Civic Club v. City of Tuscaloosa. ${ }^{109}$ Holt involved an Alabama law giving the city of Tuscaloosa "police jurisdiction" over a three-mile radius outside the city limits without a concomitant extension of the franchise in Tuscaloosa elections to residents of the extraterritorial zone.110 Citing Kramer, police jurisdiction residents contended that the denial of the franchise to them could stand only if justified by a compelling state interest. The Supreme Court, however, determined that the exclusion of police jurisdiction residents from the vote in Tuscaloosa elections was not subject to strict scrutiny, and upheld the limitation on the vote.

The Court asserted that judicial protection of the right to vote only applied to denials of "the franchise to individuals who were physically resident within the geographic boundaries of the governmental entity concerned." 111 The police jurisdiction residents were, by definition, not residents of Tuscaloosa. That police jurisdiction residents were affected by Tuscaloosa's actions did not bolster their claim to vote in Tuscaloosa elections since "[a] city's decisions inescapably affect individuals living immediately outside its borders" yet "no one would suggest that nonresidents likely to be affected by" municipal action "have a constitutional right to participate in the political processes bringing it about."112 Neither "interest" nor "impact" carries with it the right to

legislature." Id. The "policy impact" of a referendum was also seen as "different in kind" from the election of representatives-"instead of sending legislators off to the state capitol to vote on a multitude of issues, the referendum puts one discrete issue to the voters." Id.

But the Court has subjected restrictions on referenda voting to strict judicial scrutiny. For example, the Court invalidated limitations on bond issue referenda that denied the franchise to nontaxpayers. See City of Phoenix v. Kolodziejski, 399 U.S. 204 (1970); Cipriano v. City of Houma, 395 U.S. 701 (1969). Indeed, only two years before Lockport, the Court invalidated a state law requiring the concurrent approvals of the total electorate and property taxpayers for the issuance of municipal bonds. See Hill v. Stone, 421 U.S. 289 (1975). Although the state had argued that property owners, whose taxes directly and substantially fund the bond obligation, have a greater stake in the issuance of bonds than do nonproperty owners, the Court, applying the Kramer test, found that nonproperty owners were also affected when taxes on rental or commercial property are passed on in the form of higher prices. See id. at 294-97. "Although the interests of the two groups are concededly not identical," they were "sufficiently similar" to prevent the state from distinguishing between them or weighting the electoral franchise in favor of property taxpayers. Lockport, 430 U.S. at 267-68 (discussing Cipriano, City of Phoenix, and Hill).

109. 439 U.S. 60 (1978).

110. Tuscaloosa's extraterritorial authority included the power to enforce its municipal police and sanitary ordinances; license businesses, trades, and professions; and collect license fees equal to one-half that chargeable to similar businesses within the city's corporate limits. See id. at 61-62.

111. Id. at 68 .

112. Id. at 69 . 
the franchise in municipal elections for people living outside the city limits.

Holt's affirmation of the importance of formal political boundaries in marking the outer limits of the right to vote in municipal elections and in avoiding the vagaries and uncertainties of an "all-affected" principle is unexceptionable. But as in Lockport, the Court blithely assumed away the question of which of two borders-each of which had been drawn by the state-should count. The residents of the police jurisdiction were not just any group of Tuscaloosa's neighbors seeking a say in Tuscaloosa's police, tax, land use, or service delivery decisions because those municipal matters might indirectly affect them. Rather, the state had drawn a line around the Holt plaintiffs and given Tuscaloosa formal police and regulatory authority over them. To say that the "allaffected" principle is too open-ended to trigger strict scrutiny of the disenfranchisement of nonresidents cannot resolve the question of the voting rights of people resident in a territorially defined area subject to some degree to direct city control.

To be sure, Tuscaloosa's police jurisdiction authority was considerably less than the city's power over residents within the corporate limits of Tuscaloosa. The city had no power to levy ad valorem taxes, invoke the power of eminent domain, or zone in the extraterritorial belt. ${ }^{113}$ There were, thus, clear differences in the degree to which Tuscaloosans and police zone residents were affected by Tuscaloosa's actions. The limitation of the franchise to Tuscaloosa residents might, or might not, have been found to be closely tailored to the differential impact Tuscaloosa's government had on city and police zone residents under the Kramer test. The limitation on the franchise might have survived strict scrutiny. The Kramer test, however, was never applied.

The Court determined that the Tuscaloosa city limits, and not the limits of the police zone, were the only relevant border. The Holt opinion never even considered the possibility that the statute establishing the police jurisdiction might have provided the necessary, formally defined, state-authorized border for evaluating the constitutionality of a limitation on the franchise.

Lockport and Holt may be read as granting the states broad authority to determine the territorial scope of the right to vote in elections affecting local boundaries. That is how they have been interpreted by the lower federal courts ${ }^{114}$ and by the New York state courts in the secession referendum case in $1990 .{ }^{115}$ Holt's failure to treat the police

113. See id. at 73 n.8.

114. See, e.g., St. Louis County v. City of Town and Country, 590 F. Supp. 731, 737-39 (E.D. Mo. 1984); Moorman v. Wood, 504 F. Supp. 467, 472-76 (E.D. Ky. 1980).

115. The two lower New York courts were brutally dismissive of the City's arguments. See City of New York v. State, 556 N.Y.S.2d 823, 828-29 (Sup. Ct.), aff'd, 557 N.Y.S.2d 914, 916-17 (App. Div. 1990). The Court of Appeals was more measured in its disposition of the case, limiting its holding to a reading of Lockport that the State "is 
jurisdiction as even presenting a discrete local boundary may limit that decision's persuasive value. ${ }^{116}$ Lockport, however, which explicitly discusses the alternative possible definitions of the relevant constituencies, is more closely on point. ${ }^{117}$ Lockport plainly acknowledges the state's power to "recognize the realities of . . . substantially differing electoral interests" in a local reorganization and to allow the state to treat the "constituent units" of a local government as relevant jurisdictions for measuring the scope of the franchise. ${ }^{118}$ The state's authority to determine the territorial extent of the secession franchise seems particularly strong in a case, such as the Staten Island secession, in which the local subunit has both determinate borders and historical existence as a political unit for at least some local government purposes. Staten Island is not a fuzzy concept like a neighborhood, or an artificial entity

not prohibited from recognizing the distinctive interests" of Staten Islanders in being allowed "to express their views" in what the court treated as a nonbinding, advisory vote. City of New York v. State, 562 N.E.2d 118, 120-21 (1990).

116. Holt spoke of the state's authority to limit the franchise within the "geographic boundaries of the governmental entity concerned," 439 U.S. at 68 , and plainly equated "governmental entity" with "city" or "municipality." The police jurisdiction, despite its fixed borders and the specified powers of Tuscaloosa within it, was not an organized government and therefore not a "entity" for voting boundary purposes. Professor Michelman has seen in this aspect of Holt a basis for finding that the Court may hold a "constitutive understanding" of voting rights and a possible justification for Holtwhich he would find otherwise indefensible on an "instrumental understanding" of voting rights as enfranchising all interested or affected persons "residentially anchored" to the city and "within range of a substantial battery of city regulatory powers." Michelman, supra note 94 , at 478 . In his reading, " '[c]ity' would . . . signify something qualitative about the attitudes of members [of the community] toward each other or toward their common enterprise of government." Id. at 479 . That attitude would be "signified and made by moving into the community's well-defined corporate space." Id. On such a constitutive understanding of political participation, "one cannot remain aloof from the process, hover around its edges, and claim the status of a franchise member." Id.

It is difficult to see how this rationale justifies Holt (and even Professor Michelman indicates that he disagrees with the decision, see id. at 485). The residents of the police jurisdiction were not half-hearted putative citizens uncertain whether to commit to Tuscaloosa, but simply neighbors of the city who sought the franchise only because they were subject to direct regulation by the city even though neither they nor their property were physically present in the city. They might have preferred to "hover around its edges," but they were not allowed to remain "aloof from the process" because of the state legislature's action creating the police jurisdiction. Id. at 479.

Nevertheless, it could be argued that Holt is limited to situations involving a "welldefined corporate space;" and since in the secession case the only "corporate space" is New York City, Holt cannot save a voting rule that excludes the residents of the other four boroughs from the referendum franchise. Even on this reading of Holt, the state may argue that Staten Island is also a "well-defined" space which, if not literally corporate, has physical integrity, is a functioning governmental entity, and is more than a mere unorganized zone.

117. Town of Lockport v. Citizens for Community Action at the Local Level, Inc., 430 U.S. 259, 268-72 (1977).

118. Id. at 272 . 
like an extraterritorial zone, but is instead a geographically certain area that has been a county of the state for three centuries.

The Staten Island secession differs from the county reorganization in Lockport in one important way. Although the Court's analogy of the Niagara County charter change to an "impending union" or merger of hitherto separate areas is questionable, the Lockport analysis focused on annexations and consolidations-reorganizations joining together territories that had previously been under distinct governments. Lockport's approach is thus consistent with the validation of state policies that protect local autonomy by taking existing local governments as the status quo and immunizing them from fundamental alteration or dissolution without their consent.

In the secession setting, by contrast, the fundamental alteration is the detachment of a part of the city from the whole; the existing city government is the status quo. If, as the Lockport Court put it, "the fact of impending union alone would not so merge [an annexing city and the area to be annexed] into one community of interest as constitutionally to require that their votes be aggregated in any referendum to approve annexation," 119 then the fact of impending secession does not yet divide New York City into two communities of interest as to justify constitutionally the limitation of the franchise in the secession referendum to the seceding area.

This was the position of the California Supreme Court in a case involving the secession of a school district from a larger unified school district. The California Court held, Holt and Lockport notwithstanding, that the limitation of the referendum vote to residents of the seceding area was subject to strict scrutiny, and that since secession had an impact on the well-being of the district as a whole, equal protection required that voters from the entire unified school district be allowed to participate in the secession referendum. ${ }^{120}$ Thus, New York City's litigators might be able to generate a tenable argument that the City's boundaries are the relevant jurisdictional lines for determining the referendum electorate by asserting that the consolidated City is the status quo, which Lockport indicates ought to be privileged in the case of a proposed boundary change. ${ }^{121}$

\section{Id. at 271.}

120. See Fullerton Joint Union High Sch. Dist. v. State Bd. of Educ., 654 P.2d 168 (Cal. 1982). But cf. Citizens Against Forced Annexation v. Local Agency Formation Comm'n, 654 P.2d 193 (Cal. 1982) (sustaining state law limiting franchise in annexation elections to residents of territory to be annexed, when limitation furthered compelling state interest in facilitating annexations). On any theory of voting rights, Citizens is difficult to reconcile with Fullerton, decided the same day. See 654 P.2d at 188 n.1, 193 (opinion of Kaus, J., concurring and dissenting in Fullerton). The two cases are transparently outcome-driven, with the Court blocking the secession of a white area from a somewhat more racially heterogeneous school district in Fullerton, and facilitating the attachment of a moderate income area to a very affluent one in Citizens.

121. New York City's litigators have, of course, already lost their challenge to the 
But a fairer reading of Lockport and Holt is that the Supreme Court considers the entire issue of local boundary-drawing, with its attendant impact on the scope of the right to vote, to be a matter for the political judgment of state legislatures without federal constitutional limitation or guidance. The very failure to address the boundary question candidly underscores just how much the Court is willing to leave local boundaries to arbitrary state action. Both Lockport and Holt expressly invoked Hunter $v$. City of Pittsburgh ${ }^{122}$ and its traditional doctrine that the states have "absolute discretion" over municipalities, including the power to "expand or contract the territorial area, unite the whole or a part of it with another municipality, repeal the charter and destroy the corporation . . . with or without the consent of the citizens, or even against their protest."123 Hunter specifically approved the consolidation of a smaller city into a larger one, despite the contention of the smaller city's residents that the consolidation referendum failed to provide for the separate approvals of the voters of the two cities. The Court's concern in Hunter was to underscore state authority to set and remake local boundaries, not to protect the local status quo.

Although, as Kramer indicates, the state's discretion is subject to strict review when the state chooses to allow some, but not all, local citizens to participate in a decision concerning the organization of local government, Lockport and Holt return to the states the discretion to choose the territorial boundary lines within which the distribution of the franchise will be subject to strict scrutiny. The determination of the proper unit for local self-government, then, is a matter for state legislatures rather than federal constitutional review. As long as the state does not violate a specific constitutional or statutory demand, such as the ban on invidious racial discrimination, ${ }^{124}$ the definition of local boundaries is an issue for political resolution, rather than principled judicial analysis.

\section{Politics and Law in the Definition of the Secession Electorate}

The Court's reluctance to review state boundary determinations even when the right to vote is at stake is certainly excusable, and possibly justifiable. The current constitutional protection of the right to vote derives from our commitment to a political system based on democratic self-government, ${ }^{125}$ but the concept of self-government says nothing about who is the "self" that does the governing. ${ }^{126}$ There is

1990 referendum, but the issue will certainly recur when the Staten Island Charter Commission submits its handiwork for referendum approval in 1993 or 1994.

122. 207 U.S. 161 (1907).

123. Id. at $178-79$.

124. See, e.g., City of Pleasant Grove v. United States, 479 U.S. 462, 467 (1987);

Gomillion v. Lightfoot, 364 U.S. 339, 347 (1960).

125. See, e.g., Reynolds v. Sims, 377 U.S. 533, 565 (1964).

126. See Whelan, supra note 99 , at 15-16. 
no generally accepted standard for determining what makes a group of people both a discrete group (and not a collection of distinct groups) and a group distinct from other groups. ${ }^{127}$ Thus at the international level, "the theory of nationalism lacks precise and universally valid criteria for identifying a genuine nation." 128 Similarly, at the local level there is no theory for determining when one local polity ought to end and another begin.

Our political tradition ${ }^{129}$ is built on territorially based communities. Indeed, as other methods of delimiting the polity-by rank, by wealth, by race, by gender-have fallen away over time, ${ }^{130}$ the territorial definition of our polities stands out in ever sharper relief. Within a given territorial jurisdiction, the "all-affected" or "all-interested" principle invoked in Kramer holds sway, extending the franchise to virtually all adult citizens. ${ }^{131}$ The elimination of most other qualifications for the franchise has, if anything, heightened the significance of residence within the territory. Our representatives to national, state, and, increasingly, local legislatures are elected from territorial districts. ${ }^{132}$ Indeed, our entire system of local self-government rests on membership

127. Although the United Nations Charter and other international agreements recognize the principle of self-determination of peoples, in the absence of any generally accepted rule for recognizing a "people," that principle has had little impact outside the setting of decolonization. See Lee C. Buchheit, Secession: The Legitimacy of SelfDetermination 16-20 (1978). Ethnic self-determination is a particularly troublesome concept, with the criteria for marking off one ethnic group from another highly debatable, see Buchanan, supra note 24 , at $48-52$, and claims for ethnic selfdetermination often a product of specific economic or territorial grievances rather than a history of ethnic self-consciousness, see Dov Ronen, The Quest for Self-Determination 39-98 (1979).

128. Whelan, supra note 99 , at 32 .

129. To say that territorial polities are a part of our political tradition is not to say they are logically inevitable-other forms of political organization, such as occupation or social group, are available-but rather that they are the product of our history and reflect our rejection of other, more narrowing modes of political organization.

130. See, e.g., U.S. Const. amends. XV, XIX, XXIV; Harper v. Virginia Bd. of Elections, 383 U.S. 663 (1966) (holding poll tax unconstitutional).

131. The major exception is for persons who have been convicted of a felony. See Richardson v. Ramirez, 418 U.S. 24, 56 (1974). Persons adjudged mentally incompetent may also be denied the franchise. See Manhattan State Citizens' Group, Inc. v. Bass, 524 F. Supp. 1270, 1274-75 (S.D.N.Y. 1981).

The limitation of the franchise to citizens, and the consequent exclusion of adult resident aliens, raises political as well as territorial questions about the definition of a community that are beyond the scope of this article. Compare Gerald M. Rosberg, Aliens and Equal Protection: Why Not the Right to Vote?, 75 Mich. L. Rev. 1092, 1110-15 (1977) (outlining case for allowing aliens to vote) with Sanford Levinson, Suffrage and Community: Who Should Vote?, 41 Fla. L. Rev. 545, 553-58 (1989) (arguing that "[f]or the resident alien, the combination of permanent residence and overwhelming interest is not enough to warrant the ballot").

132. For an argument that democratic representation in contemporary society requires the election of representatives from territorial subunits, see Nancy L. Schwartz, The Blue Guitar: Political Representation and Community (1988). 
in territorially defined units. ${ }^{133}$ Boundaries alone mark off the scope of the arena for local self-determination and define who are the governed whose consent must be sought.

However, when the boundaries are themselves the issue to be decided, there is no uncontestably "democratic" way of deciding who makes the decision. There is no general theoretical basis for drawing territorial boundary lines, or determining whether to place a particular territory-and with it the franchise for its residents-within a particular politically salient boundary. ${ }^{134}$

The claims of New York City and of Staten Island that the City or the borough respectively is the appropriate jurisdiction for determining the referendum electorate, reduce to political arguments about which interest-the preservation of the consolidated City or borough independence-is to be favored. The two most plausible legal standardspreference for the status quo or deference to the political judgment of the state-are both arbitrary. In Lockport and Holt, preference for the status quo and deference to positive law yielded the same outcomes. ${ }^{135}$ In the case of Staten Island, however, the two principles would lead to opposite results. New York City is the existing local territorial government, so that privileging the status quo would require treating the City as the relevant voting jurisdiction. By contrast, deference to the state would allow restriction of the referendum electorate to Staten Island residents.

The determination of which principle to follow may have important implications for the political organization of metropolitan areas. In the Staten Island case, deferring to the state would facilitate the fragmentation of a metropolitan government, while privileging the status quo would prevent such an outcome. But in most cases of local boundary change and government reorganization the effects would be the reverse. Given the already extensive fragmentation of most metropolitan areas, privileging the status quo would tend to protect the independence of large numbers of independent suburban municipalities, since it would require the separate consent of each local electorate to consolidation proposals or regional government plans. Deference to the state, however, would at least leave open the possibility of state action to redraw local boundaries and reorganize metropolitan areas. The decision whether to promote or limit suburban independence is one that should be made at the state level, where the implications for all the

133. Some local units, such as special districts, are both functionally and territorially defined. General purpose local governments-counties, cities, and other municipal corporations-are purely territorial.

134. See C. Edwin Baker, Republican Liberalism: Liberal Rights and Republican Politics, 41 Fla. L. Rev. 491, 497-502 (1989).

135. This argument accepts the Lockport Court's position that functionally the county reorganization was like an annexation or merger of two distinct units. An equally plausible reading was that the status quo consisted of one integral county. 
affected localities and for the region as a whole can be considered, rather than through a voting rule that requires the consent of each locality and would allow parochial local self-interest to determine the regional fate. ${ }^{136}$ State determination would avoid the entrenchment of metropolitan fragmentation that would result from treating each existing local unit as entitled to separate electoral participation in any referendum on regional reorganization. ${ }^{137}$

Thus, deference to the state may be both an excusable response to the lack of any "democratic" legal standard for deciding the territorial scope of the vote and a justifiable alternative to an automatic preference for existing local boundaries. It is also consistent with the traditional jurisprudence of federalism that would leave state-local issues to the states.

There is one possible argument against the limitation of the referendum to Staten Islanders that would preserve general deference to state authority to determine boundaries while also protecting the right to vote against boundary-line decisions that reflect constitutionally proscribed motivations. ${ }^{138}$ In defending the legislature's action, many Staten Islanders have asserted that allowing the whole City to vote would mean that Staten Islanders would be "swamped" or "overwhelmed" by the rest of the City. ${ }^{139}$ This claim assumes that Staten Islanders and other New Yorkers will vote differently on the question, and that the other New Yorkers must be excluded because they will be hostile, or at least indifferent, to Staten Island's aspiration to autonomy. The Supreme Court, however, has repeatedly rejected limitations on the franchise intended to favor one point of view or to influence the

136. A fuller discussion of whether metropolitan governance is better served by fragmentation or regional organization is reserved for Part IV, infra.

137. This argument for state determination of the proper jurisdiction for allocation of the franchise in a local reorganization referendum reflects a belief in the desirability of state power to reconsider fragmentation. Admittedly, a preference for state power could result in state definitions of secession electorates that would facilitate secession, much as state voting rules have often facilitated the incorporation of outlying areas into independent municipalities and have hindered the ability of cities to expand through annexation. See Our Localism I, supra note 90, at 73-81.

Nonetheless, permitting the states to set the territorial basis for a local reorganization vote is preferable to either of the two principal alternatives: (i) a voting rule predicated on existing local boundaries, which would favor a fragmented status quo over the possibility of structural change; or (ii) tailoring the voting rights analysis to the facts of each case, as the California Supreme Court appears to have done in its Fullerton and Citizens decisions, in order to avoid local fragmentation and promote consolidation in each election. See supra note 120. The Fullerton/Citizens case-specific outcome-driven approach makes a mockery of the notion of a constitutionally protected right to vote.

138. Cf. Gomillion v. Lightfoot, 364 U.S. 339 (1960) (state's power to fix municipal boundaries limited by Fifteenth Amendment's protection of citizens from deprivation of franchise on account of race).

139. See, e.g., Regina Paleau, Island in the Sun, N.Y. Newsday, Oct. 10, 1990, at 54. 
outcome of an election. ${ }^{140}$

In Dunn v. Blumstein,$^{141}$ for example, the Court summarily dismissed the argument that some durational residency requirement was necessary "to impress upon [local] voters the local viewpoint." 142 Similarly, in Carrington v. Rash, ${ }^{143}$ in response to the argument of the state of Texas that military personnel newly moved into the Lone Star State might not have local interests sufficiently in mind, and therefore could be excluded from voting in state elections, the Court found that such " '[f]encing out' from the franchise a sector of the population because of the way they may vote is constitutionally impermissible." 144 In sustaining the concurrent majority rule in Lockport, the Court noted that there was "no indication" the requirement "work[ed] to favor" noncity voters over city voters. Despite the outcome in Niagara County, there are other counties where noncity voters outnumber city voters; ${ }^{145}$ in those counties the concurrent majority rule would benefit city voters. By contrast, the Staten Island secession vote limitation clearly favors one group of voters-and one outcome. ${ }^{146}$

In the end, though, this argument dissolves into the prior one concerning the definition of the proper unit for measuring the allocation of the franchise. While the state may not limit the franchise to promote a point of view, surely the state may limit the franchise to residents of a jurisdiction to assure that the views of the residents prevail in local elections and are not swamped by outsiders. Carrington and Dunn are not to the contrary, since both involved denials of the franchise to residents within a jurisdiction. Although Lockport complicates this analysis, the Court in that case did not condition its approval of the concurrent majority rule on the lack of favoritism for one group of local units. Implicit in the Court's discussion of annexation elections is an acceptance of the state's authority to structure the vote to enable residents of areas to be annexed to veto annexation.

The federal constitutional protection of the right to vote, then, leaves the determination of the proper unit for local self-government to the political processes of the states. ${ }^{147}$ Although the lack of reasoned

140. See, e.g., Reynolds v. Sims, 377 U.S. 533, 555-56 (1964); Michelman, supra note 94 , at $470-72$.

141. 405 U.S. 330 (1972).

142. Id. at 354-55.

143. 380 U.S. 89 (1965).

144. Id. at 94 .

145. See Town of Lockport v. Citizens for Community Action at the Local Level, Inc., 430 U.S. 259, 272 n. 18 (1977).

146. Although there is no certainty that New York City voters will vote against secession, or that Staten Islanders will favor it, that has certainly been the assumption of the political actors involved in the dispute.

147. There is one other federal voting rights issue. Under $\S 2$ of the Voting Rights Act of 1965, 42 U.S.C. $\S 1973$ (a) (1988), voting qualifications, standards, practices, or procedures are unlawful if they have the effect of denying or abridging the right to vote 
elaboration in the right to vote cases is disconcerting, it may be due to the intractability of the problem as well as to a substantive value of federalism to leave the matter to the states. Legal standards, if any, for scrutinizing the procedure for the secession of one locality from another are primarily a matter of state, not federal, constitutional law, and involve an analysis of the meaning and scope of state constitutional protection of local home rule.

\section{Secession and the State Constitutional Protection of Local Home Rule}

\section{A. The Indeterminacy of Home Rule Doctrine}

Most state constitutions contain a "home rule" article or amendment that provides some protection for the structural integrity of local governments and grants them some power to act with respect to local matters. ${ }^{148}$ Home rule emerged in the late nineteenth century, at a time of considerable state-local tensions. One notorious abuse of the period was the practice by rural-dominated state legislatures of adopting "ripper bills"-laws that wrested municipal functions out of urban hands and transferred them to state appointees. ${ }^{149}$ Home rule was in-

on account of race or other proscribed criteria. Local government territorial reorganizations, such as annexations, have been treated as actions with the potential for denying or abridging the right to vote, and as such may be challenged under the Act. See, e.g., City of Pleasant Grove v. United States, 479 U.S 462 (1987); City of Richmond v. United States, 422 U.S. 358 (1975); Perkins v. Matthews, 400 U.S. 379 (1971). Moreover, under $\S 5$ of the Act voting rule changes affecting covered jurisdictions must be precleared by the Department of Justice before they may take effect or be approved by the United States District Court for the District of Columbia. 42 U.S.C. $\$ 1973 \mathrm{c}$ (1988). Bronx, Kings and New York Counties are covered jurisdictions, see 28 C.F.R. $\S 51$, app. (1991), and the secession of Staten Island would have some effect on the voting rights of the residents of those counties who are protected by the Act. The secession of Staten Island would probably have to be precleared; but since this secession would increase the relative voting strength in New York City municipal elections of the minority residents of the three covered jurisdictions, see infra text accompanying note $255, \S 5$ of the Act ought not to be an obstacle to secession. Whether $\S 2$ will prove to be a barrier is likely to turn on the provisions of the Staten Island Charter and the structure of the local legislature it creates, rather than on the fact of secession itself.

Even if the constitutional protection of the right to vote were held to sustain the claim of the residents of the other four boroughs to participate in the Staten Island secession referendum, the state could avoid the City's participation in the process, without running afoul of the Equal Protection Clause, by eliminating the referendum requirement and directly authorizing the secession. There is no constitutional right to vote on local territorial reorganizations. See, e.g., Carlyn v. City of Akron, 726 F.2d 287, 290 (6th Cir. 1984) (no right to vote concerning detachment of territory from one jurisdiction and annexation to another); Berry v. Bourne, 588 F.2d 422, 424 (4th Cir. 1978) (no right to vote on annexation).

148. See Melvin B. Hill, Jr., State Laws Governing Local Government Structure and Administration 43 (1978) (home rule granted to cities in 41 states and to counties in 27 states).

149. See generally Howard L. McBain, The Law and Practice of Municipal Home Rule 1916-1930, at 5-12 (1933) (reviewing numerous instances of legislative 
tended to change the traditional rule of plenary state legislative authority over local matters, to protect cities from opportunistic, partisan state meddling, and thus to vindicate the principle of local self-government.

New York first added a home rule provision to its constitution in $1894 .{ }^{150}$ Several times amended in this century, the home rule article still offers a measure of protection against state interference with local autonomy. Currently, Article IX of the state constitution provides that the legislature has power to act "in relation to the property, affairs or government of any local government only by general law, or by special law only ... on request of two-thirds of the total membership of [the locality's] legislative body or on the request of its chief executive officer concurred in by a majority of such membership." 151 The restriction on "special laws" reflects the article's genesis in the nineteenth century concern with "ripper" legislation and other targeted state interventions in local affairs, while also preserving the state's authority to act generally with respect to local matters.

Even though this protection of local autonomy is narrow, at first glance it would appear to apply here. The Staten Island secession law is plainly a special law. It affects only one city and is written expressly in terms of Staten Island, and not for any class of municipalities. In adopting the secession measure, the legislature acted without a request-a so-called "home rule message"-from either the Mayor of New York City or two-thirds of the New York City Council. As a matter of ordinary understanding, moreover, the subtraction of one-fifth of New York City's territory and 379,000 people, the potential loss of millions of dollars of public improvements, tax base, and valuable land for future development, and the alteration of the City's political structure ${ }^{152}$ and socio-economic mix plainly and directly relate to the "prop-

"interference" with cities and the protests thus aroused). For instances of state ripper bills, see People ex rel. Le Roy v. Hurlbut, 24 Mich. 44 (1871) (state law transferring control over Detroit's water works and sewers from city to state board); People ex rel. Wood v. Draper, 15 N.Y. 532 (1857) (state law transferring New York City and Brooklyn police forces to a state-controlled metropolitan police district). See generally Jon Teaford, City Versus State: The Struggle for Legal Ascendancy, 17 Am. J. Legal Hist. 51 (1973) (historical review of home rule disputes).

150. The consolidation of Greater New York entailed submission of the consolidation bill and the city charter bill to the mayors of the cities affected, pursuant to the provision of the 1894 Constitution authorizing mayoral review and veto of special laws affecting "property, affairs, or government" of a city. The 1894 provision allowed the legislature to override a mayoral veto by simple majorities in each legislative house; hence it has been referred to as a "suspensive" veto. See supra notes 33-38 and accompanying text.

151. N.Y. Const. art. IX, § 2(b)(2). The New York Constitution provides a second exception to the ban on special laws relating to the "property, affairs or government" of a local government. The legislature may adopt such a law on a "certificate of necessity" from the governor and with the concurrence of two-thirds of both houses of the legislature. However, this exception is not available in the case of special laws affecting New York City. N.Y. Const. art. IX, § 2(b)(2)(b).

152. Staten Island's three representatives would leave the City Council and the 
erty, affairs or government" of the City.

A "plain meaning" reading of the state constitution, then, strongly supports a claim that the secession statute is unconstitutional. But in New York, as in most states, the courts have rarely provided as much scope to home rule as the text of the state constitution would suggest. As the Court of Appeals stated in Adler v. Deegan , ${ }^{153}$ New York's leading home rule case, "many words have a meaning at law different from that of common speech." 154 The court has long adhered to the view that the constitutional text does not limit the power of the legislature to act by special law with respect to matters of "state concern" even if such a law affects local property, affairs, or government. Nor does the determination of whether "state concern" or home rule applies turn on the relative balance of state or local interests. As Chief Judge Cardozo put it in Adler more than sixty years ago, "predominance is not the test" as it "involves comparisons too vague and too variable, too much a matter of mere opinion, to serve as an objective standard."155 The only "objective standard" is to allow the state to legislate by special law "if the subject be in a substantial degree a matter of State concern ... though intermingled with it are concerns of the locality."156

Thus, for the New York courts the question of whether the state legislature could authorize Staten Island's secession without the City's consent turns not on whether secession affects New York City's "property, affairs or government," but on whether secession is a matter of state concern.

1. Secession as a Matter of "State Concern." - In City of New York v. Village of Lawrence, ${ }^{157}$ the Court of Appeals treated a municipal boundary change as a matter of state concern. The court held that although "annexation or disconnection" of a city's territory "does in greater or lesser degree affect the property, affairs or government of [a] city," 158 the "property, affairs or government" language in the home rule article did not limit the legislature's power to act by special law, adopted without a home rule message, to transfer territory from the City of New York to the adjacent Village of Lawrence. ${ }^{159}$ The court interpreted the

appointees of its borough president would no longer sit on the City Planning Commission, which would alter the citywide-borough balance on the Commission.

153. 167 N.E. 705 (N.Y. 1929).

154. Id. at 706.

155. Id. at 713 (Cardozo, J., concurring).

156. Id. at 713-14.

157. 165 N.E. 836 (N.Y. 1929).

158. Id. at 841 .

159. Lawrence involved the interpretation of the home rule article of the constitution of 1894 (as amended in 1923), see supra text accompanying notes 32-34. The 1923 amendment broadened the scope of home rule protection to include "any law relating to the property, affairs or government of cities, which shall be special or local either in its terms or in its effect," N.Y. Const. of 1924, art. XII, $\$ 2$ (emphasis added), in order to overcome case law which had embraced "the fiction that a law was not local so long as it was disguised to look general." W. Bernard Richland, Constitutional City 
home rule language to refer only to "the internal affairs of a city or the functions of its officers" and not to matters affecting "the welfare of the general public as well as the residents of a city." 160 The creation of cities and the definition of their boundaries had traditionally been a matter of state power. The home rule amendment was held not to have disturbed the state's authority in this area even if "as a necessary incident the action by the Legislature may in some degree affect the property, affairs or government of a city." 161

Lawrence, however, grew out of circumstances very different from the proposed Staten Island secession, and portions of the Lawrence opinion seemed sensitive to the particular facts of that case. Lawrence involved a boundary dispute between two existing incorporated municipalities; it is difficult to see how such an interlocal conflict could be resolved other than by state law. Moreover, the state legislation involved only a minor alteration of New York City's territory-the detachment of a strip of land less than one square mile, substantially unoccupied, and without any public infrastructure. "Under such circumstances," in which "the effect upon the city is confined to a slight diminution of [its] territory," the legislature retained its power to alter municipal boundaries by special law. 162

The court indicated that in other cases

the effect of a change of the boundaries of a city upon its property, affairs, or government might be very serious. Disconnection of territory might render the existing form of government of a city inappropriate to meet the needs of its altered boundaries. It might place outside of the altered boundaries property of the city of substantial value. ${ }^{163}$

The court declined to pass on such a situation other than to leave open the possibility that it might "weigh opposing considerations and classify according to the substantial effect of the statute."164

Lawrence's potential openness to balancing was transformed by Adler $v$. Deegan, ${ }^{165}$ decided just a few months later, into a categorical ruling "that a change in boundary by the Legislature was not a law com-

Home Rule in New York, 54 Colum. L. Rev. 311,327 (1954). The 1923 amendment eliminated the mayoral suspensive veto, but provided instead that a special law relating to the property, affairs, or government of cities could be adopted only on a declaration of emergency by the Governor and on approval by two-thirds of each house of the legislature-“a requirement far more stringent than the simple majority formerly needed to override the mayor's veto." Id.

160. Lawrence, 165 N.E. at 840.

161. Id. at 841. Cf. People ex rel. Unger v. Kennedy, 101 N.E. 442, 450-51 (N.Y. 1913) (upholding state legislation that provided for the detachment of Bronx County from New York County).

162. Lawrence, 165 N.E. at 841.

163. Id.

164. Id.

165. Adler v. Deegan, 167 N.E. 705 (N.Y. 1929). 
ing within the home rule provisions."166 Adler concerned a state law dealing with living conditions in New York City's apartment houses. As one critic of the decision later noted, "the law was both salutary and badly needed," 167 but it was a special law relating to just one city and it had been enacted over the opposition of the city's government. To save the housing reform, the court interpreted the home rule article as placing little restriction on the legislature's exercise of its traditional police powers. In so doing, it recharacterized earlier home rule cases in a manner consistent with the broadest possible reading of state authority. ${ }^{168}$

Thus, Lawrence was unmoored from its particular facts: "The degree of the [boundary] change, or its importance, could not and did not affect the principle. It either was or was not a law touching the property and government of the city, and we held that it was not."169 The balancing of the relative weights of the respective state and local interests that Lawrence appeared to undertake was ruled out both in the principal Adler opinion, which first articulated the sweeping "state concern" doctrine, and in Chief Judge Cardozo's dismissal of a "predominance" test in his concurrence.

Adler and the doctrine of "state concern" drastically curtailed the immunity that home rule might have provided local governments from state interference. ${ }^{170}$ Subsequent decisions have treated Adler as a "decisively enlightening case,"'171 and have relied upon it to sustain state laws having a direct effect on basic local interests as long as the law could be linked to some matter of state concern. ${ }^{172}$ The two lower courts in the Staten Island secession referendum case treated Adler, and Lawrence as interpreted by Adler, as requiring the dismissal of the City's home rule claim. ${ }^{173}$

166. Id. at 707 .

167. Richland, supra note 159 , at 329 .

168. See id. at 329-32.

169. Adler, 167 N.E. at 707 (characterizing Lawrence holding).

170. See James D. Cole, Constitutional Home Rule in New York: "The Ghost of Home Rule," 59 St. John's L. Rev. 713, 716-18 (1985); J.D. Hyman, Home Rule in New York 1941-1965: Retrospect and Prospect, 15 Buff. L. Rev. 335, 343-45 (1965); Richland, supra note 159, at 331; Note, Home Rule and the New York Constitution, 66 Colum. L. Rev. 1145, 1149-51 (1966). Home rule as the authority of local governments to initiate local legislation has fared somewhat better in New York. See F.J. Macchiarola, Local Government Home Rule and the Judiciary, 48 J. Urb. L. 335, 357-58 (1971).

171. See, e.g., Wambat Realty Corp. v. State, 362 N.E.2d 581, 584 (N.Y. 1977).

172. See, e.g., Town of Islip v. Cuomo, 473 N.E.2d 756, 759-61 (N.Y. 1984) (municipal property used as landfill); Uniformed Firefighters Ass'n v. City of New York, 405 N.E.2d 679, 680 (N.Y. 1980) (local civil servants); Board of Educ. v. City of New York, 362 N.E.2d 948, 954 (N.Y. 1977) (percentage of local budget devoted to education).

173. City of New York v. State, 556 N.Y.S.2d 823, 826-28 (Sup. Ct.), aff'd, 557 N.Y.S.2d 914, 916 (App. Div. 1990). The trial court also placed some weight on article $\mathrm{X}, \S \mathrm{I}$ of the state constitution, which bans the creation of corporations by special law but exempts municipal corporations from that ban. Id. at 827-28. Although this article 
New York courts are not alone in applying a "state concern" doctrine to affirm the authority of state legislatures to displace local autonomy, home rule notwithstanding. ${ }^{174}$ State courts in general are reluctant to restrict the state's legislative powers to act, even in the face of home rule claims. Thus, "the class of problems considered local has become progressively narrower over time." 175 Most state courts treat municipal boundaries as interlocal matters, outside the scope of home rule immunity. It is hornbook law that a state has plenary authority over municipal boundaries: In general, states have the power to provide for the detachment or excision of a part of the municipality's territory, with or without the consent of the municipality or its inhabitants. ${ }^{176}$ State laws providing for the detachment of municipal territory have been sustained in the face of objections that they violate home rule or state constitutional prohibitions against special laws. ${ }^{177}$

Some state courts have analogized secession or detachment to annexation, emphasizing that since both have extralocal effects neither falls within the immunity for municipal "internal affairs" provided by home rule. As the Ohio Supreme Court explained, detachment has extraterritorial effects because the people and territory detached from a municipality either are placed in another municipality or create an entirely new one. Thus, detachment is not "purely local in nature," but extends beyond local borders and therefore is a matter for state determination. ${ }^{178}$ Other courts have not sought to justify the rule, but rather have simply treated it as axiomatic that boundaries, including

would sustain the incorporation of Staten Island by special law after secession, it is difficult to see how this fact answers New York City's argument that the actual detachment of Staten Island's territory from New York City by special law is unconstitutional.

174. See, e.g., Gordon L. Clark, Judges and the Cities: Interpreting Local Autonomy 113-14 (1985); Gerald E. Frug, The City as a Legal Concept, 93 Harv. L. Rev. 1057, 1116-17 (1980); Terrance Sandalow, The Limits of Municipal Power Under Home Rule: A Role for the Courts, 48 Minn. L. Rev. 643, 652 (1964). For a particularly thoughtful discussion, see City of LaGrande v. Public Employees Retirement Bd., 576 P.2d 1204, 1210-15 (Or. 1978).

175. Clark, supra note 174 , at 113 ; see also Michael E. Libonati, Reconstructing Local Government, 19 Urb. Law. 645, 646 (1987) (“[State courts] adopt a progressively constricted view of what is a purely local matter and an expansive notion of matters which are of statewide concern.").

176. See, e.g., 1 Chester J. Antieau, Municipal Corporation Law § 1B.01 (1991); 2 Eugene McQuillin, The Law of Municipal Corporations $\S 7.24$ (3d ed. 1988); C. Dallas Sands \& Michael E. Libonati, Local Government Law § 8.31 (1991). $\S 8.31$.

177. 2 McQuillin, supra note 176 , at $\$ 7.26$; Sands \& Libonati, supra note 176 , at

178. Village of Beechwood v. Board of Elections, 148 N.E.2d 921, 923 (Ohio 1958). One leading commentator agrees that detachment is like annexation, that as a result it also constitutes an assertion of extraterritorial power (albeit one that is "less obvious"), and, thus, that it is beyond the scope of home rule. See Sandalow, supra note 174 , at 694 n. 199. 
detachments, are an area of plenary legislative authority. ${ }^{179}$

Lawrence (particularly as reinterpreted by Adler), the long line of precedents it has spawned expounding and applying the doctrine of state concern, and the general treatise and case law assumption of broad state authority over municipal boundary questions, thus, would appear to dispose of the home rule question and vindicate the state's right to grant Staten Island autonomy by special law without the consent of New York City.

Yet it is not that easy, and the state's position may not even be right.

2. Secession as a Matter of "Local Concern." - The "state concern" doctrine and the cases establishing home rule's limited scope fail to capture the import, both symbolic and real, of a state law authorizing secession without the City's participation or consent. From New York City's perspective, few laws could more effectively evoke the specter of the nineteenth century state legislative interventions in municipal affairs that provided the initial impetus for home rule than this one. By shearing off one of the City's five constituent elements, the Staten Island secession legislation is a startling reminder of the "ripper" laws-and of the intense, often highly partisan state-local struggles of the past. The contrast between the effect of this law and the purpose of state constitutional home rule to protect the structural integrity of local governments from state interference is too stark to be easily ignored, even given Adler's admonition to ignore the "colloquial significance" of words and to attend to their "special, legal significance."180

Indeed, to treat the separation of Staten Island from New York City as outside the scope of New York City's "property, affairs or government" is actually to give those words a narrower meaning than they held a century ago. Proponents of the state's authority to effectuate secession have noted that Greater New York is a product of state legislation, and that the consolidation legislation was enacted over the opposition of the City of New York. They argue, in effect, that what the legislature put together the legislature may put asunder. ${ }^{181}$ These proponents, however, confuse the limited procedural protection cities received under the home rule article of 1894 with the broader substantive understanding of the meaning of municipal "property, affairs or government" expressed in the actions of the legislature that consolidated Greater New York.

In the 1890s, the state legislature submitted both the special law providing for the consolidation of Greater New York and the proposed New York City charter to the mayors of the affected cities for their ap-

179. See, e.g., Kel-Kan Inv. Corp. v. Village of Greenwood, 428 So. 2d 401, 405-06

(La. 1983); State ex rel. Andersen v. Leahy, 199 N.W.2d 713, 714-15 (Neb. 1972).

180. Adler v. Deegan, 167 N.E. 705, 706 (N.Y. 1929).

181. See, e.g., Remedies of a Proud Outcast, supra note 54, at 19; William J. Burke, The Legality of Staten Island Secession, N.Y. L.J., Apr. 5, 1991, at 1. 
proval. The 1894 constitution gave cities only a "suspensive," rather than an absolute, veto over special laws relating to municipal "property, affairs or government," so that if local consent were refused, the legislature could still enact special state legislation by repassing itwhich was, in fact, how consolidation and the charter became law. However, there was no question in 1896 that consolidation was within the home rule provision of the state constitution.

The current home rule provision of the state constitution provides localities with stronger protections against special state laws found to relate to local "property, affairs or government." The current provision would permit New York City to bar what in 1896 it could only delay. Neither the history nor the text of the state constitution indicates that municipal "property, affairs or government" should be read more narrowly than it was in 1896. If anything, home rule should have a broader meaning now than at the end of the nineteenth century.

During the course of the twentieth century, many states repeatedly revised their constitutions to expand home rule protections. These constitutional changes responded to increased public commitment to local self-government. They also represented efforts to outflank the "state concern" doctrine and restrictive judicial interpretations of earlier home rule provisions. Relatively narrow notions of the proper scope of local action in the early years of this century have been replaced by a broader acceptance of, and indeed more forceful calls for, local autonomy. New York, for example, amended its home rule constitutional amendment, which was first adopted in 1894, in 1923, in 1938, and most significantly in 1964. Currently, the home rule article declares that "[e]ffective local self-government" is a "purpose[ ]" of the people of the state, includes a bill of rights for local governments, ${ }^{182}$ and adopts a rule of liberal construction for "rights, powers, privileges, and immunities" granted to local governments under the state constitution. ${ }^{183}$ Although the more specific provisions of these amendments tend to widen local initiative to act without state legislative authorization, rather than to strengthen local immunity from state legislative interference, ${ }^{184}$ the intent to enhance the position of local governments generally relative to the state is evident.

The 1964 amendment altered the legislature's traditionally plenary authority over municipal boundary changes. Section 1(d) of the Home Rule Article specifically addresses the question of municipal annexations. It provides that no annexation may occur without the consent, by referendum, of the people in the area to be annexed, as well as the consent of the governing board "of each local government, the area of which is affected ... upon the basis of a determination that the annexa-

182. N.Y. Const. art. IX, $\S 1$.

183. N.Y. Const. art. IX, $\S 3(\mathrm{c})$.

184. Here and elsewhere in this article I have borrowed the "initiative/immunity" dichotomy from Clark, supra note 174 , at 7 . 
tion is in the over-all public interest." 185 This requirement of multiple consents for annexation is consistent with the annexation rules in many states, although only rarely have the requirements been placed in a state constitution.

The 1964 amendment, thus, constitutionalizes an aspect of local boundaries, and it does so in a manner clearly intended to protect existing boundaries from alteration by the state without the consent of the affected localities. ${ }^{186}$ Taking the amendment in combination with the other extensions of the scope of home rule, it could be argued that local boundaries are no longer a matter of "state concern," but instead should be protected as an aspect of local "property, affairs or government." Given the analogy some courts and commentators have drawn between annexation and detachment, section 1 (d) could be extended to secession cases and construed to require the consent of the governing board of the locality from which separation is sought.

This reading of the annexation provision for its spirit, however, plainly goes beyond its letter. There is no express constitutional limitation on other forms of boundary alteration, such as consolidation, dissolution, or detachment of territory. Indeed, since section $1(d)$ is limited to annexation and does not address local boundaries generally, it could be interpreted as ratifying the traditional judicial treatment of all other aspects of local boundaries as matters of state concern subject to the plenary authority of the legislature. Although it may seem odd to provide a city with greater protection against the forcible annexation to it of unwanted new territory than against the forcible detachment from it of existing and wanted territory, that is the line indicated by the text of the state constitution.

Even without attempting to fit secession within the letter of section 1(d), it may be argued that although boundary disputes generally have an interlocal dimension, and are thus outside of home rule and a fit subject for state legislative resolution, ${ }^{187}$ the Staten Island secession is not such an interlocal dispute. Many of the courts and commentators that assimilated secession to the general category of border changes and treated them all as matters for state determination were concerned with two particular types of secessions. First, there are instances in

185. N.Y. Const. art. IX, §1(d).

186. The governing boards of the affected areas do not have an unlimited right to withhold consent. The constitution requires that the decision must be based on a determination of "the over-all public interest," and it directs the legislature to provide by statute for judicial review, applying the "over-all public interest" standard, of a governing board's withholding of such consent. Id.

187. Even for clearly interlocal boundary disputes, there are dangers in allowing legislatures to proceed by special laws, since special laws present just the sort of opportunity for unprincipled meddling in local matters-of rewarding friends and punishing opponents-that home rule was intended to prevent. A strong commitment to home rule could require the state to adopt general legislation for the resolution of boundary conflicts. 
which a city initiated the process of detaching territory from itself out of a desire to avoid the burden of providing services to outlying areas. For a city-initiated detachment, treating a local border adjustment as an external matter protects the interests of the people who will be "evicted" from the city and enables the state to address the burden such an action may have on the surrounding county and adjacent municipalities. ${ }^{188}$ Second, in some cases a secession is the first step in a two-step process of shifting territory from one existing municipality in order to add it to another. ${ }^{189}$ In these cases, secession is intertwined with a subsequent annexation and the entire matter may be placed under the rubric of interlocal relations.

The Staten Island secession is quite different from these other types of secessions, which are three-party disputes with the state stepping in to resolve an interlocal conflict. This secession has been initiated by Staten Islanders, so there is no occasion to fret over the plight of residents ousted from a jurisdiction over their objection. This secession does not affect any other local government, since Staten Island already is its own county and there are no municipalities adjacent to it. Neither is Staten Island's territory being shifted to any other existing municipality. There is really no interlocal dimension to this secession-unless the embryonic "City of Staten Island" is considered to have a right to municipal life. That, however, is the issue to be decided. This factual setting of a boundary dispute without an interlocal dimension, combined with the sharp contrast between the historical purpose and common sense interpretation of home rule and the effect of the secession law on the physical and political integrity of New York City law, may explain why the Court of Appeals in the secession referendum case bridled at finding that the state had plenary power to authorize secession without a home rule message.

The Court of Appeals refrained from upholding the state's authority to redraw municipal boundaries, notwithstanding the powerful precedents on the state's side. Instead, the court determined there was no need to reach the issue of the state's power to effectuate secession without the City's consent, since the secession law only authorized the initial steps toward secession and therefore was not "an act formally triggering secession." 190 Moreover, two members of the court dissented, finding "no subject more directly concerns the affairs and government of a city than whether the integrity of its boundaries and of its existing governmental structure should be altered."191 For the dissent-

188. See, e.g., Village of Beechwood v. Board of Elections, 148 N.E.2d 921, 923 (Ohio 1958).

189. See, e.g., Carlyn v. City of Akron, 726 F.2d 287, 288-89 (6th Cir. 1984); Moorman v. Wood, 504 F. Supp. 467, 476-77 (E.D. Ky. 1980); West Point Island Civic Ass'n v. Township Comm., 255 A.2d 237, 240 (N.J. 1969).

190. City of New York v. State, 562 N.E.2d 118, 120 (N.Y. 1990).

191. Id. at 122 (dissenting opinion). 
ers, even the initial secession referendum "intrudes deeply into city affairs" and "the subject matter of the statute is essentially of local-not State-concern." 192

3. The Paradoxical Conflict Between Home Rule and Local Self-Determination. - Although it was reassuring that the Court of Appeals declined to dismiss the significant home rule issue presented by secession with a ritual incantation of the doctrine of "state concern," the Court of Appeals dissenters erred in assuming the absence of any substantial state concern in the secession issue. The state may surely be said to have a legitimate and important concern with the local government provided to its residents.

The doctrine of "state concern" recognizes the state's interest in, and ultimate accountability for, the well-being of all of its citizens, even though most of those citizens also live in towns, cities, and other localities. Many problems of importance to the state will arise in specific spatial locations; without some doctrine like "state concern," the state would be unable to respond to citizen demands-often local citizen demands-for action on such problems. ${ }^{193}$ A generous reading of the state's police power has been the longstanding foundation for modern government's ability to respond to citizen concerns. Yet broad protection of state power to act is in profound tension with home rule, as state actions may limit or supersede local decisions, and the deliberation and resolution of local issues and local conflicts are transferred to the state level. ${ }^{194}$ This conflict at the heart of home rule was perfectly captured in Adler v. Deegan, ${ }^{195}$ in which the state acted to meet the demands for improved housing quality for the people of New York City but, in so doing, displaced a decision of the City's government.

The tension between home rule and state power to respond to lo-

192. Id.

193. See, e.g., Tribe v. Salt Lake City Corp., 540 P.2d 499, 503-04 (Utah 1975) (urban blight treated as state problem even though particular blighted areas were located within individual localities with no spillover effects).

194. Ironically for New Yorkers, the importance of New York City in the political, economic, and social life of New York State has tended to mean that nearly anything important to the City is a "concern" of the State, with extensive state displacement of municipal control of local institutions and affairs as a result. See, e.g., Uniformed Firefighters Ass'n v. City of New York, 405 N.E.2d 679, 680-81 (N.Y. 1980) (prohibition of City residency requirement for city employees); In re Board of Educ. v. City of New York, 362 N.E.2d 948, 954 (N.Y. 1977) (state mandate of percentage of City's budget to be devoted to education); Salzman v. Impellitteri, 305 N.Y. 414 (1953) (state takeover of municipal transit system); Adler v. Deegan, 167 N.E. 705, 708-09 (N.Y. 1929) (state code for City housing).

On the other hand, one scholar has suggested that because of the City's size and its uniquely large percentage of the state's population, the state has accorded the City considerable institutional autonomy and administrative support. See James C. Musselwhite, Jr., A Comparative View, in The Two New Yorks: State-City Relations in the Changing Federal System 25, 30-31, 38-46 (Gerald Benjamin \& Charles Brecher eds., 1988).

195. 167 N.E. 705 (N.Y. 1929). 
cal citizen demands is particularly poignant-indeed, paradoxicalwhen the demand is for local self-government. Considerable regulatory and fiscal authority, responsibility for the provision of public goods and services, and the power to deliberate and determine a wide range of public policy questions has been delegated to local governments accountable primarily to local electorates and subject to little active state oversight. There must be some legitimate and substantial state interest in the municipal government arrangements for 379,000 people-a population large enough to constitute the second largest city in the state. Regardless of the number of people involved, it must be that just as the state can act to promote public health or civil rights at the local level, so too it may act to promote local self-government. If, because of political, economic, or social developments, sharp differences emerge within a municipality, it may become apparent to the state that the residents of a portion of the municipality will be better served if their community is carved out of the existing municipality and given local independence.

Board of Estimate v. Morris 196 increases the likelihood that such a concern will arise and makes the preservation of state power to act to meet the self-government demands of local subunits more necessary, since Morris makes it much more difficult for a state to require, or for a city to provide, special representation for a distinctive territorial subunit within the city. ${ }^{197}$ With a "federal" solution unavailable to alleviate intralocal territorial divisions, ${ }^{198}$ it may be appropriate to recognize some state power to redraw municipal boundaries not simply to address interlocal conflicts, but also to assure that all local residents have the opportunity for fair and effective local representation.

Moreover, at the symbolic level, although secession would certainly "intrude deeply into city affairs," it is not quite like the "ripper" legislation of the nineteenth century. The separation of Staten Island would not involve the arrogation of power to the state, or the transfer of control over a major local function like police or rapid transit from locally elected officials to state appointees. ${ }^{199}$ Secession does not strengthen the state in the state-local struggle for power, but rather transfers power from one local unit to another. Unlike the other forms of state intervention, secession would not entail an ongoing displacement or disruption of the relationship between local people and local

196. 489 U.S. 688 (1989).

197. See, e.g., Russell Redman, One Man, One Vote, Empire St. Rep., Dec. 1991, at 33 (Morris decision prompts suit challenging constitutionality of weighted voting scheme for representing towns in the apportionment of Nassau County Board of Supervisors).

198. Cf. Cass R. Sunstein, Constitutionalism and Secession, 58 U. Chi. L. Rev. 633, 665 (1991) (suggesting that reserving seats in a legislature for subunits to "provide a form of proportional or even super-proportional representation" is a better way to protect subunit interests than to make a constitutional provision for secession).

199. See, e.g., Salzman v. Impellitteri, 113 N.E.2d 543 (N.Y. 1953) (per curiam). 
government, or the services government provides. Rather, it is more of a surgical strike, shifting "property, affairs or government" from one local arrangement to another, but leaving municipal property, affairs, and government in some locally elected and locally accountable hands. ${ }^{200}$

As with the right to vote, the home rule question turns on the intractable problem of defining the proper unit for local selfdetermination when local interests conflict. New York City may say that the state already did that-in 1896-when New York City was created, and that thereafter home rule protects not the broad principle of local self-determination but the specific municipalities that have been incorporated. Such a bright line would certainly serve to safeguard localities from the opportunistic and partisan interventions of the nineteenth century, and to prevent the legislature from utilizing the threat of targeted detachment as a weapon in contemporary and future power struggles. Such an approach, however, would freeze historic boundaries even when, because of changing patterns of development, new concerns about growth and the optimal size of cities, and evolving attitudes about the factors that link or divide groups, residents would like to restructure those boundaries. Treating self-determination for Staten Island as solely a matter of the property, affairs, or government of New York City would place the interests of a minority in the hands of a government that may be loathe to part with a substantial number of taxpayers or the principal remaining areas of open land within the City's jurisdiction. ${ }^{201}$

Staten Island's secession is a matter of both state concern and New York City's internal affairs. The Court of Appeals majority in the secession referendum case got it right by deferring the issue, unlike the lower court judges who opted for "state concern" and the appeals court dissenters who saw only a "local concern." The "state-local" dis-

200. The secession of Staten Island could, of course, marginally reduce the influence of New York City in state-level deliberations. After secession, the City would account for a smaller proportion of the state's population and wealth, its legislative delegation would hold fewer legislative seats, and the Mayor of New York City would represent a slightly smaller constituency. Nevertheless, secession would not strengthen the state, but would instead create another local government and another local voiceincluding a local chief executive and a local legislative delegation-that would participate in state politics. That this new local interest might be adverse to New York City does not make it any less local.

201. The City could also contend that the state ought to act by general law, rather than special law, as the state has done with respect to the detachment of territory from villages. See N.Y. Village Law $\S 18-1804$ (McKinney 1973). But any general law that seeks to balance the preservation of cities against the potential for self-determination by city subunits by making the availability of secession turn on such factors as previous independence, territorial distinctness (Staten Island is an island), current formal existence as a political subdivision and not an informal neighborhood, and large population and land mass would be challengeable as a special law for Staten Island in effect if not in name. 
tinction required in Adler is difficult to draw in the best of circumstances and virtually impossible to resolve here. But if secession proceeds, the Court of Appeals will eventually have to face the question and determine on which side of the "state-local" line secession falls.

\section{B. Reconciling State and Local Concerns: The Annexation Formula as a Procedural Solution}

One way to approach secession would be to reconsider the "statelocal" dichotomy so firmly posited by Chief Judge Cardozo in Adler and recognize the presence of both interests. Although Cardozo warned that a search for a predominant interest "involves comparisons too vague and too variable," 202 the court's commitment to categorization over balancing, combined with a general reluctance to rule any areas out of the legislature's competence, has over time substantially undermined home rule. The principle that the state always wins may "serve as an objective standard," 203 but it hardly comports with the constitutional commitment to some local immunity from state interference. On the other hand, continuing to categorize but then finding no state concern in a matter in which there is some clear state interest also fails to provide a satisfactory response to a difficult state-local problem.

Under the current interpretation of home rule, either New York City can veto secession, or secession can occur without New York City's formal participation in the process. Neither approach is satisfactory. Instead, a secession procedure should recognize the presence of substantial state and local interests-and two sets of local interests-here. An appropriate formula for holding together all three interests and their overlapping commitments to local self-determination is suggested by the state constitutional provisions for annexations: ${ }^{204}$ (i) conduct a referendum in the area seeking to secede in order to get an authoritative statement of the views of the people who would obtain municipal independence; 205 then (ii) require the consent of the municipality from which they seek to secede, since that municipality would be directly and significantly affected by secession and ought to be allowed to participate in the process to protect its municipal integrity; but then (iii) provide for a state-level review of the action of the existing munici-

202. Adler v. Deegan, 167 N.E. 705, 713 (N.Y. 1929) (Cardozo, J., concurring).

203. Id.

204. N.Y. Const. art. IX, § 1(d).

205. This procedure need not preclude a referendum of the voters in the remainder of the city, who may also wish to be heard on the issue. However, whereas a negative referendum vote in the area proposed for secession would end the matter, a negative vote in the remainder of the city would not be dispositive, although it would provide other decision-makers with relevant information concerning the attitudes of the city's electorate. If a majority of the voters in the remainder of the city actually supported secession, that could make it easier for the city's elected officials to give their consent or for state reviewing officials to find that the secession is in the "overall public interest" of the city. 
pality, a review that could overturn the denial of consent to secession on the basis of the "overall public interest" of the region.

This procedure would have the value of treating seriously the claims to self-determination of both Staten Island and New York City, while preventing either group from taking unilateral action to the detriment of the other. New York City would be allowed to participate in the process, but it could not veto secession. The "over-all public interest" review would provide for a final, state-level determination, and at least provide some possibility of a decision that is both principled, with the reviewing body giving reasons for its action, and contextualized to the specific circumstances of the existing municipality and the area seeking secession. ${ }^{206}$ As with every other aspect of the secession dispute, however, there are difficulties with this solution: How would the procedure be adopted, and how would the "overall public interest" standard be given meaning in this setting?

Though it is not clear that the Court of Appeals has authority to impose this procedure, the court could interpret the annexation provision of the state constitution to apply of its own force to secessions. Similarly, the court could treat the annexation provision as indicative of the constitutional status of municipal boundaries, and weave it together with the "property, affairs or government" language of home rule to establish a secession procedure that would combine the City's formal participation with the authority of the State to override the City's denial of consent. Either approach would require a liberal infusion of the home rule "spirit" of the constitution into its more straitened letter, but either would also be consistent with the constitution's emphasis on the protection of local autonomy. This procedure could also, of course, be adopted by the legislature through an amendment to the secession process.

In the absence of a legislative amendment or of a judicial willingness to find such a procedure in the existing home rule text, the Court of Appeals should invalidate, on home rule grounds, any secession legislation adopted without the City's participation in the process. One reason is pragmatic: Invalidation of such a secession enabling law is the less drastic of the two alternatives. Whereas sustaining a secession measure would actually separate Staten Island from New York City without the City's participation, invalidating the secession enabling act would simply preserve the status quo, including the possibility of a subsequent secession accomplished in a procedurally fair manner.

More generally, a requirement of City participation or consent as part of the secession process should not be seen as an absolute barrier to secession, but rather should be treated as the predicate for trilateral

206. This is similar to the procedure for secession-literally "deannexation"utilized in New Jersey. See, e.g, Ryan v. Mayor of Demarest, 319 A.2d 442 (N.J. 1974); West Point Island Civic Ass'n v. Township Comm., 255 A.2d 237 (N.J. 1969). 
(state-city-Staten Island) negotiations over the determination of Staten Island's share of the City's debts and other liabilities and the sale or transfer of City-owned property on Staten Island to any new City of Staten Island. Should secession actually occur, some allocation of New York City's assets and liabilities would have to be made, either by state imposition, negotiation, or litigation. The requirement of New York City's consent to secession would not only constitute a proper recognition of the City's interest in home rule but would also give the City the bargaining chip it needs to protect its interest in the New York-Staten Island "divorce settlement." 207 Secession could still occur and the Staten Islanders' interest in self-determination would be protected, but only if they, or the state, would be willing to strike a deal that addresses some of New York City's fiscal concerns.

Beyond the pragmatic, secession under the procedure outlined in the 1989 and 1990 legislation-that is, state-mandated detachment of a sizeable portion of municipal population and territory with no formal role for the municipality-is simply too great an affront to the notion that the constitution creates some sphere of municipal autonomy with respect to local "property, affairs or government." Although the judicial exegesis of home rule has departed considerably from the constitutional text, that text, the rejection of the targeted state interventions in local matters that gave rise to constitutional protection for home rule in the nineteenth century, and the evolving aspiration to greater local autonomy that has led to repeated constitutional amendments expanding the scope of home rule in the twentieth century, all reflect a concern to provide some formal legal protection for the political integrity of local governments against state interference.

Neither the history of the New York constitutional home rule article nor the concept of home rule itself plainly resolves the validity of the present secession legislation. But judicial approval of state legislation that authorizes secession without giving New York City any role at all in the procedure would be a statement that a city need not even be consulted about a state action with major implications for its territorial and structural integrity. Government actions have an expressive and educational component as well as instrumental effects. ${ }^{208}$ Secession under the procedure outlined in the 1989 and 1990 legislation, and judicial ratification of that course, would be an expression of disdain for the very idea of home rule for existing municipalities and a public statement of how little a constraint home rule places on state actions. The state has, and must continue to have, the power to regulate interlocal

207. Similarly, Staten Island's ability to bring a secession measure to the legislature with the prospect that it will receive serious consideration enhances Staten Island's ability to bargain with the City over the terms of secession, or over the City-Staten Island relationship even if Staten Island remains in the City.

208. Philip B. Heymann, How Government Expresses Public Ideas, in The Power of Public Ideas 88-100 (Robert B. Reich ed., 1990). 
relations, control local actions, protect local residents, and reorganize the governance of metropolitan areas to promote regional well-being. However, a secession procedure that assumes that an existing local government has no legal interests in existing territorial and political arrangements departs too far from the model of some state protection of local autonomy that home rule presupposes.

Assuming the Court of Appeals applies the constitutional annexation procedure to secession, or the legislature adopts a secession procedure modelled on the annexation provision, there would still be considerable difficulty in determining the content of any "over-all public interest" standard and deciding what state-level institution ought to apply it. The annexation provision vests reviewing authority in the courts, which have tended to view the "over-all public interest" standard through the framework of cost-benefit analysis. In effect, the courts have attempted to tot up the advantages and detriments of boundary change in terms of the scope and expense of municipal services and facilities, and to see if the gain to the area benefitted by boundary change outweighs any harm to the area losing territory. ${ }^{209}$ Aside from the inherently speculative nature of these calculations, this approach permits one unit's benefit to offset another unit's loss, even though the beneficiaries do not compensate the losers, thereby ignoring distributional concerns. Alternative approaches in the annexation case law in other states seem to entail putting a finger on the scaleeither by finding that any significant hardship to the seceded-from locality weighs heavily against secession ${ }^{210}$ and thus favoring the status quo, or by focusing primarily on whether there are gains to the area seeking secession. ${ }^{211}$ These approaches serve only to raise once again the question of which local unit is the more appropriate focus of the commitment to local self-determination.

The analysis of "overall public interest" might be advanced by looking past the determination of benefits and costs for the particular localities and considering the question in terms of the normative values advanced by local governments in a metropolitan area. Would the metropolitan area as a whole be better served by the break-up of one large municipality into two smaller ones? Conversely, are there normative concerns that counsel in favor of continuing the consolidation of Greater New York?

The standards for evaluating the benefits and costs of secession to the region would be subject to normative debate, and the data concerning efficiencies, externalities, and wealth transfers between the secessionist subunit and the rest of the city that would be marshalled by the

209. See, e.g., Town of Lansing v. Village of Lansing, 438 N.Y.S.2d 29 (App. Div. 1981); City of Saratoga Springs v. Town of Greenfield, 312 N.Y.S.2d 4 (App. Div. 1970).

210. See, e.g., Ryan, 319 A.2d at 447-49.

211. See, e.g., West Point Island Civic Ass'n v. Township Comm., 255 A.2d 237, 241 (N.J. 1969). 
opposing sides would inevitably be hotly contested. Such a polycentric, polyvalent analysis, entailing a combination of empirical expertise and metropolitan policy-making, is inherently political rather than judicial, suggesting that the public interest standard ought to be applied by the legislature rather than the courts. ${ }^{212}$

Legislative action ought to include consideration of the City's objection to secession, assessment of the likely impact of secession on the well-being of the metropolitan area, and justification for any decision to override the City's position. The meaning of "overall public interest," then, would emerge out of this combination of data collection and analysis, presentation and examination of opposing positions, and legislative articulation of the reasons for its conclusions. One way to accomplish this, including the development of a formal record and the provision of an opportunity for all the relevant interests to be heard, could be through the use of a special commission. The legislature has, in fact, created a special commission in its current secession legislation; but that commission, which is composed solely of Staten Islanders, is intended solely to consider the implications of secession for Staten Island and to devise Staten Island's post-secession future. Its mandate is not to assess the consequences of secession for the rest of New York City. A different commission-one which included representatives of the City as well as of Staten Island-would be necessary to examine the likely consequences of secession for the City, the region, and the Island. Its report would provide independent research and analysis concerning the implications of secession for the metropolitan region, reports which would enable the legislature to take the action in the "overall public interest." 213

Although a full-scale analysis of the consequences of secession for the well-being of the region is well beyond the scope of this Article, the next Part undertakes some of the preliminary work, proposing a normative framework and suggesting some of the practical criteria that ought to be considered by the legislature in ultimately determining the secession question.

212. The issue could also be delegated to an administrative agency. Indeed, a number of states utilize administrative agencies for the resolution of boundary questions. See, e.g., Our Localism I, supra note 90, at 81-85. Administrative agencies could certainly be appropriate for the collection and analysis of data concerning the economic consequences of secession. However, the administrative agency's evaluation of the meaning of its data would clearly entail the application of political values. Moreover, the process of appointment to the agency would take on considerable political significance-particularly if the agency were created solely to deal with the Staten Island question, or even if Staten Island were simply the first item on its agenda.

213. In addition to its participatory, fact-finding, and deliberative features, a procedure consisting of a local referendum, formal participation by New York City, study by a special state commission with representatives from the affected areas, and ultimate decision by the legislature would resonate closely with the procedure that culminated in the creation of consolidated New York at the end of the last century. 


\section{Secession and the Structure of Metropolitan Governance}

\section{A. Theoretical Perspectives}

Just as there is no one theory for determining the proper territorial scope of a polity, so too there is no generally accepted standard of how to govern a metropolitan area. The debate over the appropriate structure for metropolitan governance has been informed by concerns for efficiency, equity, and democracy. In this setting, efficiency refers to the capacity of government to deal effectively with problems of regional scope and to provide public goods and services at low cost. ${ }^{214}$ Equity consists of all area residents receiving public services of comparable quantity and quality, with the costs of those services distributed fairly across the region. ${ }^{215}$ Democracy includes representation of and accountability to area residents affected by public decisions as well as the opportunity for people to participate in their own collective governance. ${ }^{216}$ There are, of course, considerable tensions among these imperatives. A government structure may have to trade off some of one value in order to make progress towards another, and it is likely that no institutional design will be able to achieve all these goals simultaneously. ${ }^{217}$

At one time, the dominant school of thought emphasized the benefits of unified area-wide government. Only metropolitan government, it was asserted, would have sufficient institutional capacity, public resources, and regional perspective to provide those services-such as water supply, sewage disposal, pollution control, and transportationthat need to be handled on an area-wide basis. ${ }^{218}$ Similarly, only metropolitan government would be able to engage in the comprehensive area-wide planning necessary to permit coordinated regional development and reduce the costs of duplication and overlap. ${ }^{219}$ Metropolitan

214. See Advisory Commission on Intergovernmental Relations, Metropolitan America: Challenge to Federalism 30-31 (1966) [hereinafter ACIR]; Howard W. Hallman, Small and Large Together: Governing the Metropolis 180-82 (1977).

215. See ACIR, supra note 214, at 166; Scott A. Greer, Governing the Metropolis 114-17 (1962); Hallman, supra note 214, at 204.

216. See ACIR, supra note 214 , at 32 .

217. The existence of a trade-off between efficiency and equality has long been a staple of the political economy literature. See, e.g., Arthur M. Okun, Equality and Efficiency: The Big Trade-off (1975). A comparable trade-off may exist at the local level between facilitating citizen participation and creating a local government capable of dealing effectively with area problems. See Robert A. Dahl \& Edward R. Tufte, Size and Democracy 20-25 (1973) (contrasting "citizen effectiveness" and "system capacity"); cf. Kenneth A. Shepsle, Representation and Governance: The Great Legislative Trade-Off, 103 Pol. Sci. Q. 461 (1988) (suggesting that internal reforms that made Congress a more representative body also weakened it in conflicts with the President).

218. See, e.g., Luther H. Gulick, The Metropolitan Problem and American Ideas 24 (1962).

219. The most prominent call for the consolidation of existing local governments into larger units came from the report of the Research and Policy Committee of the Committee for Economic Development, Modernizing Local Government to Secure a 
government would also promote equity since all the people of a region could call upon the regional tax base for the support of public goods and services. Finally, an area-wide government would promote democracy: since a region was believed to share a set of common interests binding residents together into a common community, a metropolitan government was necessary to represent and respond to the interests of such a regional community. 220

These analysts criticized metropolitan fragmentation and pressed for regional governments. As suburban opposition repeatedly doomed the consolidation proposals that would have created centralized regional governments, reformers developed proposals for "two-tier" or "federative" plans that would move certain governmental functions to the regional level while reserving others to pre-existing local governments. ${ }^{221}$ However, for most of this century there has been little political movement toward consolidation, ${ }^{222}$ and today many metropolitan areas are fragmented into large numbers of localities. ${ }^{223}$

Balanced Federalism (1966); see also Amos H. Hawley \& Basil G. Zimmer, The Metropolitan Community: Its People and Government 2-3 (1970) (positing that consolidation of many political units into one municipal government would eliminate conflicting jurisdictions and create adequage tax base for revenue); Vincent Ostrom et al., Local Government in the United States 64-81 (1988) (presenting and criticizing this view).

220. See, e.g., Greer, supra note 215 , at 145-46.

221. See Committee for Economic Development, Reshaping Government in Metropolitan Areas 19-20 (1970). The "two closest approximations" to the Committee for Economic Development's two-tier model are Miami-Dade County, Florida, which utilizes the existing county as the basis for a metropolitan-level government, and Toronto, Canada, which has a "true federative government." John J. Harrigan, Political Change in the Metropolis 318-21 (4th ed. 1989).

222. The only significant consolidations, involving 250,000 or more people, in the last half-century have been the two-tier metropolitan government in Miami-Dade County, Florida, and the city-county consolidations of Nashville-Davidson County, Tennesee, Jacksonville-Duval County, Florida, and Indianapolis-Marion County, Indiana. Generally, most consolidation proposals require voter approval for adoption, and suburban voter resistance has been effective in blocking most such proposals. See generally John E. Filer \& Lawrence W. Kenny, Voter Reaction to City-County Consolidation Referenda, 23 J.L. \& Econ. 179 (1980) (rejection of consolidation proposals in suburban voters' economic self-interest); Vincent L. Marando, City-County Consolidation: Reform, Regionalism, Referenda and Requiem, 32 W. Pol. Q. 409 (1979) (as city-county wealth disparity increases, consolidation through referenda less likely).

223. See Bureau of the Census, U.S. Dep't of Commerce, Local Government in Metropolitan Areas 37-74 (1985) (table 3). As evidence of the extent of contemporary metropolitan area fragmentation, in 1982 there were 121 municipalities in Cook County, Illinois; 89 in St. Louis County, Missouri; 56 in Cuyahoga County (Cleveland), Ohio; and 123 in the three New York counties of Nassau, Suffolk and Westchester combined. Id. A more recent study of St. Louis County, Missouri-which does not include the City of St. Louis-reported 91 municipalities, including 23 with fewer than one thousand residents and 71 with fewer than ten thousand residents. See Ronald J. Oakerson \& 
In recent decades, as if in synch with the popular mood, ${ }^{224}$ scholarly opinion has shifted away from consolidation. It is frequently argued today that efficiency and democracy concerns, at least, are more likely to be addressed successfully in a fragmented metropolis.

The "most influential argument" 225 against metropolitan government derives from the public choice model, which grows out of the work of Charles Tiebout. In his seminal article, $A$ Pure Theory of Local Expenditures, ${ }^{226}$ Tiebout saw, in the large numbers of local governments and the relative ease of individual movement from one locality to another, a "market-type solution" to the question of how to determine the level and mix of government expenditures responsive to popular desires. The multiplicity of local governments in a metropolitan area means that, as long as each locality is free to adopt its own mix of services, regulations, and charges, residents will be offered a wide array of types and levels of public services and a wide variety of rates of taxation. An individual, as a "consumer-voter," can decide on the type and level of services she wishes to receive and the tax burden she is willing to assume by "shopping around" among the various localities in a metropolitan area before "purchasing" by moving to the one that best suits her interests. ${ }^{227}$ A large number of localities assures a range of choices and increases the possibility that one place will meet the mobile consumer-voter's preferences. Municipal fragmentation promotes the ease of relocation from one community to another and thereby helps create a metropolitan market in public services.

Other public choice adherents have focused on the influence consumer-voter movement exerts on local decision-making. Local governments will compete to retain their current taxpayers and to attract new ones. This competition constrains local taxing and spending decisions and penalizes administrative inefficiency, thereby improving the general responsiveness of local government to consumer-voter concerns while holding down the overall local government costs. In this sense "rivalry among local governments is analogous to rivalry among firms" in the provision of consumer goods. ${ }^{228}$

Roger B. Parks, Citizen Voice and Public Entrepreneurship: The Organizational Dynamic of a Complex Metropolitan County, Publius, Fall 1988, at 91, 96.

This extensive metropolitan fragmentation is due, in part, to legal changes that have facilitated separate suburban incorporation and restricted the authority of cities to annex new territory. In particular, cities must generally obtain the consent through referendum of incorporated suburban areas as a condition to annexation or consolidation. See generally Our Localism I, supra note 90, at 72-85 (discussing local government formation laws).

224. Cf. Ostrom et al., supra note 22, at 73 (citing "popular resistance to metropolitan reform" as a "source of doubt" about the wisdom of metropolitan government).

225. Harrigan, supra note 221 , at 309 .

226. 64 J. Pol. Econ. 416 (1956).

227. Id. at 417.

228. Ostrom et al., supra note 22, at 206. Cf. Mark Schneider, Intermunicipal 
Public choice, thus, tends to oppose the consolidation of smaller localities into larger units; ${ }^{229}$ indeed, it celebrates the multiplicity of local units as the very guarantor of the capacity of the metropolitan municipal services marketplace to accommodate differences in personal preferences for public goods and services and to facilitate interlocal competition. ${ }^{230}$ The more governments there are in close proximity to each other, the easier the exit mechanism that makes the whole model work.

In addition to interlocal competition, public choice localists see in small local governments, in contrast to the elephantine proportions of metropolitan units, a likely source of efficiency. ${ }^{231}$ They contend that scale economies turn into diseconomies and drive up the unit costs of public services as localities grow past a certain point, and although the economically optimal local size is debatable, they assert it is far below that of most of America's big cities today. ${ }^{232}$

Public choice's preference for metropolitan fragmentation on efficiency grounds is reinforced by a strand of contemporary political theory that promotes local government as a setting for individual participation in public life. ${ }^{233}$ In other words, "voice" as well as "exit"

Competition, Budget-Maximizing Bureaucrats, and the Level of Suburban Competition, $33 \mathrm{Am}$. J. Pol. Sci. 612, 625-26 (1989) (reviewing literature and finding that "on the margin" an increase in number of governments in a region constrains size of government but also noting that other factors, including region, intergovernmental aid, and local wealth, affect municipal service expenditures).

229. See Ostrom et al., supra note 22, at 182-86; Robert L. Bish, The Public Economy of Metropolitan Areas 55-56 (1971). Public choice theorists are critical of restrictions on the incorporation of new municipalities, see Robert Warren, A Municipal Services Market Model of Metropolitan Organization, $30 \mathrm{~J}$. Am. Inst. Planners 193, 202-03 (1964), and metropolitan-area-wide government has been condemned as a form of "full line forcing" that compels a taxpayer to pay for an entire package of government activities rather than allowing him to select among various types and levels of public services. See Richard A. Wagner \& Warren E. Weber, Competition, Monopoly, and the Organization of Government in Metropolitan Areas, 18 J.L. \& Econ. 661, 672 (1975).

230. See Warren, supra note 229 , at 196.

231. Cf. Jane Jacobs, The Question of Separatism: Quebec and the Struggle over Sovereignty 70-77 (1980) (discussing as one of the "paradoxes of size" the inefficiency and bureaucracy that accompany large organizations).

232. See, e.g., Hallman, supra note 214, at 192-93 (citing studies suggesting that population needed for scale economies is from 40,000 to 200,000 ).

Some contend that smaller units are also likely to reduce the costs of participation in local politics. The "transactions" costs necessary for a collective body to reach a decision relate directly to the size of the polity; the larger the group and the more interactions within it, the more time and effort a collective decision will entail. So, too, the costs of being on the losing side of political decisions tend to correlate with the size of the polity, since bigger units are typically more heterogeneous and more people in such units are likely to have preferences that diverge from the median. In smaller, homogeneous units, there may be less internal disagreement, and thus fewer local losers. See Bish, supra note 229, at 51-52.

233. Participation is valued as a form of personal political empowerment and as a means for building a sense of community. See generally Richard Briffault, Our 
may support the multiplicity of governments in urban areas. ${ }^{234}$ Participation in public collective decisions, it is asserted, can only occur in small political units. ${ }^{235}$ Small size facilitates the deliberative process, the exchange of information and ideas, that is at the heart of participation. People in small units are believed to understand more about the issues at stake and to know more about each other, thereby facilitating public-spirited decision-making. ${ }^{236}$ Furthermore, people in smaller units may be more familiar with each other's needs and characteristics, which in turn gives rise to greater good will, cooperativeness, and other traits conducive to collective action. ${ }^{237}$ Smaller units may have a greater sense of community, and communality and participation will be mutually reinforcing. The sense of community facilitates participatory decision-making, and participation builds up the sense of community. ${ }^{238}$

In addition, people in smaller units may be more likely to believe that their participation counts, that they can make a difference. The individual is more capable of being heard and of influencing a signifi-

Localism: Part II-Localism and Legal Theory, 90 Colum. L. Rev. 346, 393-95 (1990) [hereinafter Our Localism II] (reviewing legal scholarship suggesting connection between local government and political participation). Participation has also been seen as an education in self-government, enabling people to learn about the issues, processes, and institutions of government, equipping them with "individual attitudes and psychological qualities," and providing them with an opportunity for "practice in democratic skills and procedures." Carole Pateman, Participation and Democratic Theory 42 (1970).

234. For a public choice argument for metropolitan multiplicity that emphasizes "voice" over "exit," see Roger B. Parks \& Ronald J. Oakerson, Metropolitan Organization and Governance: A Local Public Economy Approach, 25 Urb. Aff. Q. 18, 24 (1989). For discussion of the convergence of "voice" and "exit" arguments in support of local government fragmentation, see Our Localism II, supra note 233, at 403-05. The origin of the "exit" and "voice" typology of mechanisms for collective decisionmaking is, of course, Albert O. Hirschman, Exit, Voice and Loyalty: Responses to Decline in Firms, Organizations, and States (1970).

235. See, e.g., Frug, supra note 174, at 1068-70; Clayton P. Gillette, Plebiscites, Participation and Collective Action in Local Government Law, 86 Mich. L. Rev. 930, 952 (1988).

236. Clayton Gillette puts it in economic terms: Small size permits repeated interactions among identifiable members of the community. Once people see that fellow community members are willing to look to the common good, they will also put community interest over self-interest. Gillette, supra note 235, at 985. For Jane Mansbridge, small size permits "face-to-face contact" and the attendant benefits of "empathy and commitment to the common good." Jane J. Mansbridge, Beyond Adversary Democracy 270, 275 (1980).

237. See Robert C. Wood, Suburbia: Its People and Their Politics 266-67 (1959).

238. But see W.E. Lyons \& David Lowery, Governmental Fragmentation Versus Consolidation: Five Public-Choice Myths about How to Create Informed, Involved, and Happy Citizens, 49 Pub. Admin. Rev. 533, 540 (1989) (study consisting of surveys of residents of five matched pairs of communities located in two metropolitan areas finding little difference in fragmented area residents' versus consolidated area residents' 1) knowledge about government, 2) extent of participation in local affairs, 3) or sense of efficacy about relationship with local government). 
cant portion of the community. The resulting enhanced sense of "citizen effectiveness" 239 will lead to more participation, which, by confirming the sense of effectiveness, will contribute to continued participation.

Proponents of decentralized metropolitan governance have responded to the assertion that many localities will be too small to provide basic services and that a politically fragmented region will be incapable of dealing effectively with area-wide problems by contending that these issues can be addressed, without consolidation, through interlocal agreements. ${ }^{240}$ In this way the decisions whether and how much of a public service to provide can be made in a small local unit, but the service itself can be produced and supplied by a larger entity if that makes economic sense. ${ }^{241}$

Proponents of metropolitan multiplicity have been less concerned with responding to criticisms grounded in equity. As local public services are largely funded out of local tax bases, the division of metropolitan areas into localities of widely divergent tax bases creates considerable interlocal fiscal disparities, and concomitant inequalities in the cost and quality of local public services. ${ }^{242}$ These fiscal disparities are closely connected to differences in the race, class and personal

239. Robert A. Dahl \& Edward R. Tufte, Size and Democracy 61-62 (1973).

240. Local governments can purchase services from each other, form joint ventures or create special purpose districts to supply services on a regional basis. See Robert L. Bish \& Vincent Ostrom, Understanding Urban Government 59-69 (1973); David J. Elazar, Building Cities in America: Urbanization and Suburbanization in a Frontier Society 145-47 (1987); Vincent Ostrom et al., The Organization of Government in Metropolitan Areas: A Theoretical Inquiry, 55 Am. Pol. Sci. Rev. 831, 838-42 (1961). Some participationists also support the idea of resolving regional issues through interlocal agreements. See, e.g., Gerald Frug, Empowering Cities in a Federal System, 19 Urb. Law. 553, 561-63 (1987).

Localities that are too small to provide basic services themselves can contract to buy them from other governments. The model for this is the so-called Lakewood Plan, named after a community in Southern California. In the 1950s, Lakewood was an unincorporated area that sought to avoid annexation by the city of Long Beach. It devised a plan to incorporate as a new city but to contract with the county to receive all the county services it had previously received plus additional services necessitated by population growth. Lakewood became the first municipality to exist on the basis of purchasing all of its basic services from another unit of government. In the seven years following Lakewood's innovation of its plan in 1954, twenty-five suburban communities in Los Angeles County incorporated into independent municipalities. See generally Gary J. Miller, Cities by Contract 10-22 (1981) (outlining political origins of the Lakewood Plan).

On the role of interlocal agreements and special districts in the creation and preservation of small local governments, see Our Localism II, supra note 233, at 374-80.

241. See Parks \& Oakerson, supra note 234, at 21-22.

242. These enormous interlocal wealth differences-with a particular locality's wealth having little or no connection to the extent of its service needs-are the premise of the school finance reform litigations that have moved through the courts of at least two dozen states. See Our Localism I, supra note 90, at 18-39. 
income of local residents. Indeed, fragmentation promotes interlocal and interpersonal inequalities, as more affluent people relocate to higher wealth jurisdictions. They are able to enjoy the enhanced local public services at a lower tax rate that only a substantial tax base can provide, while simultaneously immunizing their resources from the revenue demands of highly taxed, financially strapped central cities where the poor and the dependent are increasingly concentrated. ${ }^{243}$

Neither the public choice nor the participationist case for small local units gives much attention to the interplay of interlocal and interpersonal wealth differences, public service disparities, and the multiplicity of local governments in a region. Instead, they assume that these inequalities are to be addressed at the state or federal level, through programs that could make the wealth of a jurisdiction less significant in determining the cost or quality of local public services. ${ }^{244}$ Such programs, however, have yet to materialize in any serious way. ${ }^{245}$ Indeed, federal urban policy is currently in retreat, with the federal government today providing dramatically less assistance to local governments than it did in $1980,{ }^{246}$ and the states doing only a little to fill

243. See Our Localism II, supra note 233, at $425 \&$ n.343; Harrigan, supra note 221, at 309-10; Miller, supra note 240, at 196-202; Gregory R. Weiher, The Fractured Metropolis 87-144 (1991).

244. These could include federal and state grants-in-aid; federal or state assumption of the financial responsibility for certain services, such as education and welfare, that are now at least partially locally funded; area-wide taxes or tax base sharing; and state authorization for central city taxation of commuters' incomes earned in the cities. See, e.g., Hallman, supra note 214, at 204-11.

245. As many intergovernmental assistance programs either reward existing levels of local effort or are provided to all local governments, intergovernmental aid, even when well-funded, is only modestly redistributive. See, e.g., Miller, supra note 240 , at 188 (finding that in 1976 two of the wealthiest high-income cities in Los Angeles County received federal aid of $\$ 12$ and $\$ 28$ per capita, while two of the poorest, low-income cities received $\$ 5$ and $\$ 9$ per capita).

State efforts to assume more of the financial responsibility for education, the most important locally funded service, have been halting at best. See Our Localism I, supra note 90, at 18-39, 59-64. Minnesota has adopted a form of tax-base sharing for the Twin Cities, see Our Localism II, supra note 233, at 449-50, but this step has not been followed by other states. Only 18 of the 86 largest cities in the United States have authority to impose any kind of income tax. Six of these 18 cities are in Ohio, but three of them may not tax any commuter income, and four other cities are required to tax commuter in-city earnings at a much lower rate than may be applied to city residents' earnings. See Helen F. Ladd \& John Yinger, America's Ailing Cities: Fiscal Health and the Design of Urban Policy 126-27, 132-34 (1991).

246. Federal aid to cities declined from $18.4 \%$ of cities' own-source revenue in 1982 to $7.5 \%$ of cities' own-source revenue in 1988 . The federal aid share of city budgets in 1988 was significantly lower than it was in 1972 . The effect of the drop in federal aid more than offset the fiscal benefits that accrued for the average central city during the economic expansion of the 1980s. See Ladd \& Yinger, supra note 245, at 323-24. Among other actions, the federal government in the 1980s eliminated general revenue-sharing and imposed budget cuts of more than $45 \%$ on such urban aid programs as urban development action grants, housing subsidies, and employment and training programs. See id. 
the financial void created by federal abandonment of the central cities. ${ }^{247}$ Under these circumstances, interlocal inequality is the Achilles' heel of all arguments for a fragmented metropolis.

\section{B. Theoretical Perspectives in Practice: The Case of the Staten Island Secession}

1. The Case for Secession. - Although many contemporary scholars have opposed the idea of metropolitan consolidation, they have focused more on resisting further central city expansion and on preserving small units than on the dissolution of existing large cities. ${ }^{248}$ Nevertheless, from both the public choice and political participation perspectives, Staten Island is an appealing case for municipal independence.

For both sets of theorists, small is beautiful, or at least smaller is presumptively better than bigger. As the largest city in the United States, with a population greater than that of most states, New York City must be too large to be efficient or to provide its citizens with the opportunities for involvement in the critical aspects of public life that make local autonomy so attractive. As Robert Dahl put it from a participationist perspective, " $[t]$ o regard the government of New York as a local government is to make nonsense of the term."249 Dividing New York City into two smaller municipalities-the smaller portion wellpositioned to reap the political and economic benefits of smaller sizewould clearly be an improvement.

Furthermore, there would be no uncertainty as to what ought to be the boundaries of the new entity-the question that has led to bloodshed in the fragmentation of Yugoslavia and the former Soviet Union ${ }^{250}$ - since the boundaries of Staten Island are clearly marked by

247. Id. at 324-27.

248. However, a direct discussion of secession from a public choice perspective can be found in James M. Buchanan \& Roger L. Faith, Secession and the Limits of Taxation: Towards a Theory of Internal Exit, 77 Am. Econ. Rev. 1023 (1987).

Political localists have given less direct attention to the structure of governance in metropolitan areas than have their economic counterparts. Gerald Frug, for example, defines "city" expansively "to include the concepts of neighborhood and regional government." Frug, supra note 174, at 1061.

249. Robert Dahl, The City in the Future of Democracy, 61 Am. Pol. Sci. Rev. 953, 968 (1967); see also Douglas Yates, The Ungovernable City 178 (1977) ("City hall is obviously too large to be a viable neighborhood government . . ..").

250. One aspect of the conflict that has wracked Yugoslavia has been the armed efforts of Serbs to detach Serb-populated areas that fall within the jurisdictional boundaries of Croatia, and the Croat resistance to that effort. See, e.g., David Binder, The Serbs and Croats: So Much in Common, Including Hate, N.Y. Times, May 16, 1991, at A14; Blaine Harden, Serbia Wields Power in Balkan Struggle; Croats Retreat Before Guerrilla Drive, Wash. Post, Aug. 6, 1991, at A8. Similarly, the former Soviet republics of Azerbaijan and Armenia are locked in a bloody struggle over the jurisdictional status of Nagorno-Karabakh, an enclave within Azerbaijan but populated primarily by ethnic Armenians. See, e.g., H.D.S. Greenway, Old Foes, Freed From Empire, Rage Anew, Boston Globe, Mar. 17, 1992, at 1. In addition, there are tensions 
geography and by historic political lines. Nor can there be any concern that Staten Island would be too small for municipal independence; with 380,000 people it would actually be far larger than the optimal city size dictated by most theoretical formulas. ${ }^{251}$

Under a public choice analysis, secession ought directly to benefit Staten Islanders in the Tieboutian sense of improving the match between their preferences for local public services and the services they actually receive from local government. ${ }^{252}$ Similarly, government in a smaller city ought to be easier to influence, and the transaction costs of political participation could be greatly reduced. Moreover, Staten Island demonstrates both a considerable amount of internal homogeneity in such areas as race, socio-economic status, land use, home ownership, and household composition, and substantial differences in these areas and in political affiliation from the rest of the City. ${ }^{253}$ With their

between Ukraine and Russia over the status of Crimea. The peninsula was historically a part of Russia, but was awarded to Ukraine by the central authorities in the Soviet Union in 1954. Some in Russia would like the territory returned, but Ukraine insists on maintaining its current jurisdictional alignment. See, e.g., Celestine Bohlen, In RussiaUkraine Fight over Navy, Crimea Lies at the Heart of the Struggle, N.Y. Times, Mar. 31, 1992, at A6.

251. See supra note 232 .

252. It is a very different question whether secession would "benefit" Staten Islanders in the sense that Staten Islanders would receive better public services for the taxes they pay, or conversely would be able to pay less taxes for the services they currently receive. The question of whether, in effect, Staten Island is a net contributor to or a net recipient from the rest of New York City, is beyond the scope of this Article.

253. Staten Island's population is $80 \%$ non-Hispanic white; in the City overall nonHispanic whites account for just $43.2 \%$ of the population. See 1990 New York Census Summary, supra note 12 , at 107 (Table 4).

The average family income is about $38 \%$ higher on Staten Island than in the rest of the City, with $61 \%$ of Staten Island households having incomes greater than $\$ 25,000$, compared to $42 \%$ in the rest of the City. See Independence Feasibility Study, supra note 15 , at 15 .

Staten Island's land is primarily devoted to residential housing: only $5 \%$ of the assessed real estate parcels on Staten Island fall into the two non-residential assessment classes. In the City as a whole, $9 \%$ of the assessed parcels are non-residential, with that percentage rising to $17 \%$ in Manhattan. Measured by assessed value, $53 \%$ of the property on Staten Island is residential, compared to $41 \%$ for the City as a whole and $31 \%$ for Manhattan. See New York City Dep't of Finance, Annual Report on the New York City Real Property Tax, Fiscal Year 1992, at 19-24 [hereinafter Real Property Tax Report 1992].

Moreover, $63.7 \%$ of Staten Island's housing units are owner-occupied, as opposed to just $\mathbf{2 8 . 6 \%}$ in the rest of the City. See 1990 New York Census Summary, supra note 12, at 289 (Table 12). In a city fabled as the home of apartment-dwellers, $82.1 \%$ of Staten Island housing units are in structures of just one to four units; the comparable figure for the City as a whole is just $36.1 \%$. See id. at 199 (Table 8). Staten Island is also distinctly more oriented to the traditional family than is the rest of the City: $59.5 \%$ of Staten Island households are married-couple families, whereas just $38.9 \%$ of households in the rest of the City are. See id. at 133 (Table 5).

With respect to political affiliation, Staten Island may be more heterogeneous, but very different from the rest of the City. The City as a whole is overwhelmingly 
own municipality, more Staten Islanders may be on the winning side of municipal decisions than they have been in the past. This could increase their satisfaction with and reduce their costs from local political decisions.

Under the public choice model, the benefits of secession extend beyond Staten Island. By creating a municipality immediately adjacent to New York City, secession would increase the tax-service package options available to current New Yorkers and facilitate the possibility of exit for residents of the remaining four boroughs. Admittedly, in a region that has over two thousand local governments, including seven hundred municipalities, ${ }^{254}$ New York area residents already enjoy a wide array of tax-service package options, and it may be questioned just how much one new city would add to the metropolitan marketplace. Staten Island is, however, an area of comparatively large territorial scope and includes considerable developable land; at the margin, at least, its independence would provide some consumer-voters with a new and potentially inviting place in which to shop for the municipal facilities they desire, and a haven from the City taxes they might like to avoid. Indeed, without having to exit New York City, some City residents might benefit from the very existence of an independent Staten Island since the presence of this additional municipal "competitor"which would be the next largest city in the state and would be in close proximity to the Manhattan central business district-might constrain the taxing and spending practices of New York City.

It is even possible that some remaining New Yorkers, including those with no intention or desire to move, might benefit from the departure from New York City's political arena of a bloc of voters (and their representatives in the City Council) with views on taxes, services, and public policy generally at variance from their own. Apartmentdwellers and businesses in Manhattan, for example, might gain from the departure of a part of the constituency that has fought hard to keep down property taxes on single-family homes and shift the tax burden to multiple occupancy dwellings and commercial and industrial proper-

Democratic: $70 \%$ of the City's registered voters-and $81 \%$ of the voters who have chosen to enroll in a party-are Democrats; only $14 \%$ of registered voters and $16 \%$ of party enrollees are Republicans. See The Green Book 1991-92: The Official Directory of the City of New York, at 468-69 [hereinafter Green Book 1991-92]. In Staten Island, the division is much closer, with the Democratic edge among registered voters $50 \%$ to $30 \%$, and among party enrolled voters $60 \%$ to $36 \%$. See id. In recent elections Staten Island has voted for Republicans for President, for Mayor, and for Borough President, while the rest of the City was electing Democrats to those offices. See id. at 4 . In addition, Democrats on Staten Island may differ from the rest of the City's Democrats in terms of political priorities. See James C. McKinley, Jr., Staten Island Democrats Warn Dinkins on Support, N.Y. Times, Oct. 29, 1991, at B3.

254. See Michael N. Danielson \& Jameson W. Doig, New York: The Politics of Urban Regional Development 4 (1982) (1977 study finds 2191 governments, including 780 municipalities, in 31 -county tri-state region). 
ties. ${ }^{255}$ More generally, the remaining New Yorkers could benefit from the lower decision-making costs that might follow from the reduction in the City's size, although the loss of population relative to the size of the City is quite small and the transaction costs savings would be fairly marginal.

Despite these theoretical benefits, secession would be a mixed blessing. Secession is highly problematic under all three of the values-efficiency, equity, and democracy - that have animated the debate over metropolitan governance. A preliminary examination of the secession of Staten Island as a case study in metropolitan organization indicates how fragile the case for fragmentation is, and how tenuous the assumptions underlying the public choice and participationist models are. Moreover, secession reveals some interesting tensions within the participatory and communitarian conception of democracy that has generated the call for greater autonomy for small political units.

2. The Case Against Secession.

a. Efficiency and Externalities. - An efficiency-based defense of secession would have to come to grips with the increase in the external effects of local government actions. The public choice model assumes that the consequences of local actions are borne primarily within the acting locality, that is, that they are "internalized." Tiebout makes this premise express: in his idealized model, local government will be efficient only when locally supplied public services "exhibit no external economies or diseconomies between communities."256 New York City and Staten Island, however, would not be self-contained municipalities, set apart from each other. Instead the two are closely intertwined around a common harbor, a shared economy, and an overlapping physical infrastructure. The decisions of each city are certain to affect the other directly. Although the existence of externalities is an inevitable consequence of multiple governments in metropolitan areas, and might not by itself be sufficient to promote the further consolidation of New York City with other localities in the region, surely the increase in external effects must be considered when the break-up of a city is proposed. ${ }^{257}$

The operations of the Fresh Kills landfill, the Staten Island site

255. New York City's one- and two-family homes are notoriously underassessed relative to both other property in the City and similar residential parcels in the adjacent suburbs. See Roger Starr, The Rise and Fall of New York City 194 (1985); Gerald C.S. Mildner, New York's Most Unjust Tax, NY: The City Journal, Summer 1991, at 21, 21.

If Staten Island's departure could increase the relative clout of apartment-dwellers, then, by the same token, single-family home-owners in Brooklyn and Queens could be worse off after the secession of their allies.

256. Tiebout, supra note 227 , at 419 ; see also Vincent Ostrom et al., The Organization of Government in Metropolitan Areas: A Theoretical Inquiry, $55 \mathrm{Am}$. Pol. Sci. Rev. 831, 840-42 (1961) (examining problems created when provision of public goods cannot be confined to boundaries of existing governmental units).

257. See also Our Localism II, supra note 233 , at 426-27. 
where virtually all of New York City's solid waste is discarded, ${ }^{258}$ reflects the interconnection of the two areas. The fate of Fresh Kills, should Staten Island become independent, is uncertain since New York City could retain ownership of the landfill even if it is outside of the City's reduced municipal territory-the City owns reservoirs that form a substantial portion of its water supply although they are located at some distance from the City in upstate New York. ${ }^{259}$ Whichever city gets the landfill, the other will be the loser. If New York City retains ownership, the City would have less incentive to respond to Staten Islander complaints about smells, hours of operation, transport practices of truckers and barges, and other problems, since the complainants are no longer constituents. On the other hand, if Fresh Kills is transferred to Staten Island ownership, Staten Islanders have already indicated an intention to rely on the fees New York City would be required to pay to continue to use the facility in order to provide a secure financial base for the newly independent municipality. ${ }^{260}$

Beyond physical infrastructure, each city would have a stake in the laws and policies of the other. According to a study commissioned by a leading secession proponent, most of the personal income of Staten Islanders is earned in the other four boroughs of New York City. ${ }^{261}$ The City's tax and regulatory practices, its decisions concerning the na-

258. See Independence Feasibility Study, supra note 15, at 12.

259. The uncertainty of the fate of the landfill derives from the uncertainty as to whether the state would have to pay New York City compensation if the City is divested of ownership. This uncertainty, in turn, is traceable to the murky "governmental/ proprietary" distinction in local government law, and ultimately to the origins of municipal corporations as hybrid public/private entities. See Hendrik Hartog, Public Property and Private Power: The Corporation of the City of New York in American Law, 1730-1870 (1983); Joan Williams, The Development of the Public/Private Distinction in American Law, 64 Tex. L. Rev. 225 (1985) (reviewing Hartog book).

Under Hunter v. City of Pittsburgh, 207 U.S. 161 (1907), a state may take property held by a local government in its governmental capacity without paying compensation, but, in dictum, the Supreme Court indicated that compensation may be required for property held in a proprietary capacity. See id. at 179. The governmental/proprietary distinction is notoriously difficult to draw. See, e.g., Janice C. Griffith, Local Government Contracts: Escaping from the Governmental/Proprietary Maze, 75 Iowa L. Rev. 277 (1990). Although in later cases the Court indicated a reluctance to require states to pay compensation for the taking of proprietary municipal property, see City of Trenton v. New Jersey, 262 U.S. 182 (1923), the takings doctrine in this area remains cloudy. Moreover, state law may require compensation for the taking of municipal property. See Rudolph V. Parr, Comment, State Condemnation of Municipally-Owned Property: The Governmental-Proprietary Distinction, 11 Syracuse L. Rev. 27 (1959). In New York, " $t]$ he cases are in disarray" as to when compensation would be required. Id. at 34 .

260. See Independence Feasibility Study, supra note 15, at 2, 4. Other issues of infrastructure interdependency would include the water supply for Staten Island (New York City owns the water and the connections between Staten Island and upstate reservoirs but might be compelled by the state to supply it at the "municipal" rate), the operations of the Staten Island Ferry, and responsibility for New York harbor.

261. See Remedies of a Proud Outcast, supra note 54, app. A at 21. 
ture and scope of service delivery, and its investment in public goods and services in the other four boroughs will have direct effects on the business climate and on the possibilities of economic growth and development-or decline and decay. These will, in turn, affect the substantial number of Staten Islanders who make a living in the rest of the City, as well as the remaining Staten Islanders who depend on those commuters.

Conversely, New York City would be affected by the land use practices on Staten Island. While the City would not want to lose any current taxpaying residents or businesses to a newly independent Staten Island, it would be much better for New York City if the businesses and residents that emigrated settled on Staten Island than if they moved further afield. Businesses in Staten Island might provide jobs for New Yorkers, and residents of Staten Island might continue to return to the City to work and shop. Staten Island's zoning laws and land use regulations, thus, would have a direct impact on New York, and yet after secession the City would have no role in setting those rules. ${ }^{262}$

Public choice theory suggests that local governments can deal with the problems of spillovers through a process of interlocal bargaining, accommodation, informal understandings, and contracts. ${ }^{263}$ Agreements, presumably, could be worked out in all these areas of potential dispute or shared interest. This, however, seems implausible.

Instances of voluntary interlocal cooperation ${ }^{264}$ in areas like land use planning and zoning, taxation, and general public expenditures are rare. ${ }^{265}$ Indeed, it would be naive to think that any city would be willing to bargain away its municipal birthright to make policy decisions in the core areas of local autonomy. As the strenuous resistance of state legislators from Long Island and Westchester to New York City's proposal to increase the personal income tax levied on commuters sug-

262. The City's past stewardship of land development on Staten Island has been the subject of considerable controversy. Many have criticized the City for permitting in the 1960s and 1970s "unfettered private sector" development, with the consequent construction of " "jerry-built, rubber-stamp rowhouses," " scattered across the Island "with no consideration given to drainage, access, or the availability of city services." Danielson \& Doig, supra note 254, 107-08 (quoting noted architecture critic Ada Louis Huxtable). An alternative perspective would be that the City allowed less exclusionary zoning on Staten Island than is commonplace in the suburban communities in the region.

263. See supra note $225-238$ and accompanying text.

264. Some of these issues - the landfill, the water supply, the ferry-are so basic to the separation of Staten Island from New York City that, I assume, they would have to be worked out at the time of secession. In effect, they are issues for the state legislature in determining whether, and on what terms, secession may occur. Although these questions could, therefore, be answered at the outset of Staten Island's independence, their resolution would be imposed by the state and not worked out through the voluntary interlocal bargaining central to the localist model.

265. See Our Localism II, supra note 233, at 431-33. 
gests, ${ }^{266}$ it is difficult to believe that Staten Islanders would ever offer to contribute to the maintenance and improvement of municipal services in Manhattan even though Staten Island commuters would directly benefit.

Any belief that interlocal disputes can be worked out by voluntary agreement must be predicated on the assumptions that the leaders and peoples of the two cities will approach each other with cool, rational attitudes conducive to reaching agreements. However, it is more likely that passion will outrank reason in a post-secession New York CityStaten Island relationship, especially if, as is probable, secession occurs only after a hard-fought struggle. As Abraham Lincoln reminded the seceding Southerners in the First Inaugural Address: "Physically speaking, we cannot separate. We cannot remove our respective sections from each other, nor build an impassable wall between them." 267 Staten Island and New York City, like the North and South,

cannot but remain face to face; and intercourse, either amicable or hostile, must continue between them. Is it possible then to make that intercourse more advantageous, or more satisfactory, after separation than before? Can aliens make treaties easier than friends can make laws? Can treaties be more faithfully enforced between aliens, than laws can among friends?268

To be sure, not every spillover from City or Staten Island action would mark an increase in the total cost of local government in the New York area. Some external effects of an independent Staten Island might simply reflect the reallocation of the expenses of certain public services, such as solid waste disposal or ferry service, from Staten Island to the rest of the City, or vice versa. Given the costs and benefits of these services, some such reallocation might be appropriate, and even with the likely increase in intergovernmental tensions, it is certainly possible that the total efficiency savings from the separation of Staten Island could outweigh the externality costs. The point of this attention to externalities here is that even the strong efficiency case for decentralization is not free from doubt, and requires a close attention to the degree of public service and regulatory integration of Staten Island with the rest of New York City and to the costs of separation and independent provision.

b. Equity. - The secession of Staten Island would raise numerous equity concerns, although equity ultimately proves to be as slippery a

266. See Vivienne Walt, Dinkins' Budget Plan Placed on Legislature's Back Burner, N.Y. Newsday, May 14, 1991, at 91; Frank Lynn, Legislative Races Linked to City Problems, N.Y. Times, Oct. 28, 1990, § 12 (Long Island Weekly), at 1; Sarah Lyall, Dinkins Commuter-Tax Plan Gets Cool Reception on L.I., N.Y. Times, Oct. 23, 1990, at B2; Rex Smith, Albany Report: Koch's Tax Suggestions Face Resistance, N.Y. Newsday, May 8, 1989, at 19.

267. Abraham Lincoln, First Inaugural Address, reprinted in Abraham Lincoln, Speeches and Writings, 1859-1865 (Library of America 1989) 215, 221.

268. Id. at 222. 
criterion as efficiency and fails to be dispositive of the merits of secession. First, the purported efficiency benefits of secession would be unequally distributed. The central lever of the economic model is interjurisdictional mobility, but not all people are equally mobile. Movernent is constrained by a variety of economic and social factors that tend to affect poorer people more than affluent ones. ${ }^{269}$ Limits on personal resources as well as differences in "tastes" for municipal services will determine which New Yorkers avail themselves of the opportunity to exit to an independent Staten Island. ${ }^{270}$ Of course, to say that some would benefit more from secession than others does not itself require a conclusion that secession is inequitable. ${ }^{271}$

Second, a Staten Island secession would constitute a loss of wealth and tax base for New York City. Admittedly, with only five percent of the city's population and an even smaller percentage of its assessed valuation, Staten Island constitutes only a minor portion of the City's tax base. ${ }^{272}$ There is relatively little commercial or industrial activity on Staten Island, 273 and the single-family homes that dominate Staten Island's housing stock are notoriously underassessed. ${ }^{274}$ Indeed, upon independence Staten Islanders might face a hefty increase in the local property tax since they would no longer benefit from the Manhattan central business district office properties that are the core of the City's tax base. ${ }^{275}$

Still, the departure of Staten Island could reduce the City's eco-

269. These include the out-of-pocket costs of relocation, the limited range of job opportunities available to people lacking education or skills, the costs of commuting, and the lack of affordable housing in the places that might be desirable sites for relocation. See Our Localism II, supra note 233, at 420.

270. See Ladd \& Yinger, supra note 245, at 293-94; John R. Logan \& Harvey L. Molotch, Urban Fortunes: The Political Economy of Place 39-43 (1987).

271. Arguably, the departure of Staten Island could worsen the political position of those New Yorkers for whom exit is too costly to be a viable alternative. The existence of an independent Staten Island may make the City's government more sensitive still to the allocative demands and policy preferences of the more affluent New Yorkers for whom exit has become a more credible option. Thus, a Staten Island with lower taxes and better middle class services just across the harbor may help tilt the balance against poorer New Yorkers in the City's ongoing internal municipal class struggles over the type and distribution of public services. On the other hand, by removing a middle class component from the City, secession could strengthen the relative strength of the poor in the City's politics. Cf. supra note 255.

272. For fiscal year 1992, real property on Staten Island has an assessed valuation of $\$ 2.76$ billion, or approximately $3.3 \%$ of the City's total assessed valuation of $\$ 83.6$ billion. See Real Property Tax Report 1992, supra note 253, at 19, 24.

273. Only $4.98 \%$ of the real estate parcels and $33.85 \%$ of the assessed valuation fall within Class IV, which is commercial and industrial property. This compares with $8.64 \%$ of real estate parcels and $53.36 \%$ of assessed valuation Citywide-and $17.13 \%$ of parcels and $65.62 \%$ of valuation in Manhattan. See id. at 19-24.

274. See supra note 255.

275. See Peter Passell, Economic Watch: Can S.I. Flourish Without New York City?, N.Y. Times, July 7, 1989, at B1. 
nomic strength. At a time of extreme fiscal stringency and in an era of chronic urban crisis, the loss of any fraction of the City's tax base would be a blow, and the secession of Staten Island would affect sales and income tax payments as well as the tax on real property. In addition, as the one borough with significant open spaces, Staten Island has been and is likely to continue to be the area of the city where population and property values are most likely to increase. This potential tax base growth would be lost to the City after secession. ${ }^{276}$

Of course, tax base is only one side of the fiscal equation. It is certainly possible that Staten Islanders consume more in municipal services than they pay in local taxes. This actual "balance of trade" between the Island and the rest of the City is uncertain. If Staten Island were in effect a drain on the municipal coffers, the argument from lost tax base would obviously have considerably less force, although the loss of land for development and the potential for future tax base growth would remain.

A broader equity implication of secession would be the degree to which it would effect a separation of the relatively affluent from the relatively needy. The average family income on Staten Island is about thirty-eight percent higher than in the rest of the City, with sixty-one percent of Staten Island households having incomes greater than $\$ 25,000$, compared to forty-two percent in the rest of the City. ${ }^{277}$ Staten Island has the highest percentage of high school graduates, the highest median family income, the lowest percentage of families with no workers, and the smallest incidence of families below the poverty line of any borough in the City. ${ }^{278}$

The Staten Island-City differences, however, should not be exaggerated. This would be not so much the "secession of the successful," 279 as the secession of the socio-economic center. Staten Island is not a wealthy enclave, but a solidly middle-class borough. ${ }^{280}$ Its residents are less well-heeled than many area residents; its affluence is relative to the rest of the City. Still, the secession of Staten Island would be yet another instance of the intermunicipal separation by class, income, and race that is so characteristic of the United States today.

Secession would enable Staten Islanders to escape from New York City's economic and social problems while continuing to benefit from proximity to the City and access to its jobs, public facilities, and cultural resources exactly as it did prior to secession. Although most of the personal income of Staten Islanders is earned at work in the rest of New

276. See Danielson \& Doig, supra note 254, at 262.

277. Independence Feasibility Study, supra note 15, at 15.

278. See Bohanek, supra note 46 , at 39 .

279. Robert B. Reich, Secession of the Successful, N.Y. Times, Jan. 20, 1991, § 6 (Magazine), at 16; cf. Buchanan, supra note 24, at 16-17 (discussing issues raised by the "secession by the better off").

280. See Bohanek, supra note 46 , at $40-42$. 
York City, ${ }^{281}$ after secession they would be liable to pay no more than a trivial commuter income tax, held down by the legislature to a small fraction of the City personal income tax. ${ }^{282}$ Commuters directly benefit from certain city services-police and fire protection, traffic control, road maintenance, mass transit, and the water supply. ${ }^{283}$ They benefit indirectly from all local public spending that promotes the economic and social well-being of the place where they earn their living. ${ }^{284}$ Studies have found a close correlation between the per capita cost of city services and the commuter percentage of city employment. ${ }^{285}$ Given the constraints on City taxation of commuters and the absence of any provision for municipal tax base sharing, secession would provide Staten Islanders with "the sweet" of the New York City economy without "the bitter" of the taxation necessary to address New York City's pressing needs. ${ }^{286}$

Staten Island, of course, would be no better off than other suburban jurisdictions that also depend on a central city for the financial well-being of many of their residents. That, however, just restates the general problem posed by the existing fiscal structure of metropolitan areas in which commuter suburbs are able, through municipal independence, to reduce greatly their contribution to the pressing needs and costs of the center city's poor and to the tax burden of the remaining urban middle class. ${ }^{287}$ Whether the reduced fiscal support departing

281. Remedies of a Proud Outcast, supra note 54, app. A at 21.

282. Compare N.Y. Tax Law $\S \S 1304,1304-A$ (McKinney 1989) (highest marginal rate of taxation on income earned by City residents is $3.4 \%$ plus $0.51 \%$ surcharge) with N.Y. Gen. City Law $§ 25-\mathrm{m}-2-A$ (McKinney 1989) (tax on nonresidents' earnings in New York City is $0.45 \%$ of wages and $0.65 \%$ of net earnings from self-employment). Suburban representatives in the state legislature have strenuously resisted all City efforts to increase the commuter tax, including Mayor Dinkins' plan to earmark increased commuter tax revenues for public safety programs. See sources cited supra note 266. As secession would shift Staten Island's legislative delegation from the interests of the City to that of the suburbs, the likelihood of any increase in the commuter tax would be further reduced.

283. See Ladd \& Yinger, supra note 245, at 87, 296.

284. As Ladd and Yinger have found, much of the benefit of city economic development programs and the increase in urban employment during the prosperity of the 1980s actually accrued to non-city residents. In effect, much of central city job growth consists of jobs held by commuters. See id. at 25 .

285. See id. at 87.

286. Senator Marchi's study candidly states that one scenario for the Island's future development is a "symbiotic" relationship with New York City, with Staten Island "a bedroom-style community priding itself on increased levels of desired services to homeowners but continuing to remain dependent on New York City for jobs." Remedies of a Proud Outcast, supra note 54, app. A at 21; see also Independence Feasibility Study, supra note 15, at 32 (similar scenario "assumes a continuing symbiotic relationship with New York City within which the quality of life on Staten Island is improved significantly" and that "any scenario for the future of Staten Island is grounded in the economic and demographic conditions of New York City and the New York-New Jersey Metropolitan Statistical Areas").

287. Some studies, however, have questioned the "suburban exploitation" thesis, 
suburbanites provide to central cities creates an inequity is uncertain, however, because the normative obligation of suburbanites to cities is an unresolved issue.

In our society, arguments for redistribution tend to operate within borders; that is, the notion of a duty to provide support for the needy and afflicted proceeds largely from a sense of membership in the same community. "[I]t is often said that our positive obligations to our fellow citizens are much more substantial than those we have toward 'strangers.'"288 "Community" could include nation, state, city, or neighborhood, but where the equity issue is raised in the context of a municipal secession, the concern is that the secessionist subunit, particularly if it is a relatively prosperous one, is seeking to reduce the burden of local taxes paid to assist the local poor. From a central city perspective, such a secession would be an instance of the affluent shirking their obligations. But once the secession is actually accomplished, the secession area would have no greater obligation to the poor of the city left behind than would any other members of the broader society.

In other words, whether secession is inequitable turns on a background assumption of a duty of distributive justice based on common membership in a community. However, to say that members of a community have duties to each other tells us nothing about how a particular community is to be defined. The leitmotif of the voting rights and home rule discussions-should an area be treated as one polity or more than one-recurs in determining the social duties as well as the political rights of metropolitan area residents. Duties appear to follow from borders, not the other way around.

The positive consequences of the secession of a relatively affluent area from a city can be seen clearly in the loss of fiscal support for the central city and its increasingly needy residents, but the normative characterization of such reduced support as "inequitable" is undetermined. The real source of inequity is not secession but the fragmentation of metropolitan government into wealth- and income-segmented municipalities, unaccompanied by adequate higher level government mechanisms for redistributing resources from high-wealth to high-need jurisdictions. So long as our governmental structure permits radical interlocal differences in fiscal resources and the quality of support for local public services, it is difficult to censure one part of the metropolitan area for seeking to follow the same path of isolation from central city needs marked out by so many other suburban jurisdictions.

suggesting that the suburban commuter contribution to the economic prosperity of the city and the concomitant enhancement of city property values offsets the suburban use of city services and suburban benefit from city economic activity. See David F. Bradford \& Wallace E. Oates, Suburban Exploitation of Central Cities and Governmental Structure, in Redistribution Through Public Choice 43, 45-51 (Harold M. Hochman \& George E. Peterson eds., 1974).

288. Buchanan, supra note 24 , at 115 . 
Finally, secession raises an equity concern that is different in kind from that created by the incorporation of previously unincorporated areas on the urban outskirts. As previously noted, the distinctive feature of a secession is the departure of people who take their land and the fixtures appurtenant to that land with them. Staten Island differs from other suburban communities in the metropolitan area in that for a century it has directly benefitted from New York City's creation of a public infrastructure on the island. Indeed, secession could constitute a redistribution of wealth from the City to Staten Islanders in the most literal sense: they would probably receive the extensive municipal physical infrastructure built on the island. At the time of consolidation, Staten Island's "development was hampered by inadequate transportation, and by the absence of unified schools, satisfactory water, sewer, police and fire protection."289 The provision of "Catskill water supply, electric street lights, paved roads and sidewalks, and sewers" all followed in the decades after consolidation, and was paid for by the taxpayers of New York City. ${ }^{290}$ By the City's estimate, there are today 650 miles of sewers, 885 water pipes, 33,475 street lights, 1,025 miles of paved streets, 3 municipal hospitals, 3 police stations, 18 firehouses, 11 libraries, and 55 schools on Staten Island ${ }^{291}$-all of which were provided by the City of New York out of municipal taxation over the course of the century. While New York City could continue to use the Fresh Kills landfill and would, no doubt, vigorously defend its ownership of that facility, it is difficult to see how or why the City could retain ownership of the sewers, water pipes, streets, and street lights and other public infrastructure intended to serve the people in the immediate vicinity. Thus, if Staten Island were to secede, those facilities would most likely be turned over to the newly independent municipality.

Whether this redistribution of municipal wealth constitutes an inequitable expropriation would then turn on whether the City receives fair compensation. The "governmental/proprietary" distinction is often fuzzy, but this property would most likely be considered governmental, ${ }^{292}$ so that neither the state nor the independent City of Staten Island would have to pay New York City compensation. In the absence of a legal duty, the state still might provide compensation for New York City's investment on Staten Island, either to win New York City's consent to separation if such consent proves legally necessary or because the politics of enacting secession legislation might require it. In short, the existence of considerable New York City investment on Staten Island that would probably pass to a new municipality raises an important

289. Jacqueline Overton et al., Long Island and Staten Island since the Revolution, in 10 History of the State of New York 135, 166 (Alexander C. Flick ed., 1937).

290. Id.

291. See Affidavit of Joel Berger at Exhibit C, City of New York v. State, 556 N.Y.S.2d 823 (Sup. Ct. 1990) (No. 46770/89).

292. See supra note 259. 
fairness concern, but that concern could be addressed in the terms of separation and need not pose an absolute barrier to secession. ${ }^{293}$

c. Democracy. - The relationship of secession to democracy is as debatable as the implications of secession for efficiency or equity. Secession also raises questions concerning the connection between participatory democracy and homogeneous communities that bring out the ambivalence within the participationist argument concerning the value of homogeneity in localities. On the one hand, much of the case that local autonomy enhances the possibility for effective participation is based on assumptions of shared interests, experiences, values, and norms in local communities. ${ }^{294}$ Common backgrounds, goods, and concerns promote an empathy conducive to collective decision-making and increase the possibility that individuals will be able to put aside their own self-interest for the local common good. ${ }^{295}$ This implicitly assumes a significant amount of homogeneity of interests at the local level, and tends to establish a case for homogeneity as a vital component of effective, politically active local communities.

On the other hand, much of the rhetoric about the virtues of local autonomy celebrates the potential for the resolution of difference through discussion, deliberation and debate. The educational component of local public life is built around people learning from each other and together building bridges across their differences toward the resolution of common problems. This theory, of course, assumes differences and places a positive value on local heterogeneity.

As already noted, the secession of Staten Island would be a move toward greater homogeneity for both Staten Island and New York City along many of the lines of division in our society. Staten Island is a predominantly white, middle class, home owner community. It is far less diverse along the dimensions of ethnicity, class, land use, and household structure than the rest of the city. There would simply be far fewer economic and social differences in an independent Staten Island than in the city it would leave. There might be fewer wrenching municipal issues to struggle over as well. Staten Island is certainly much less subject to the social stresses and strains that so burden New

293. Related to the "equitable distribution" of the municipal property on Staten Island is the allocation of the obligation to repay New York City's indebtedness. The departure of Staten Island, with its property tax base and its location as a site for transactions subject to the City sales tax and as a home for residents subject to the City personal income tax, arguably impairs the security of New York City's bondholders, an interest they may enforce through the Contracts Clause. The secession of Staten Island would have to include some assignment of a portion of New York City's debt to the new city. The formula for such an allocation-which could be based on the share of New York City's population on Staten Island, the share of the debt-funded capital infrastructure on the Island, or other factors-would surely be subject to debate.

294. See Dahl \& Tufte, supra note 239, at 13-14; Mansbridge, supra note 236, at 270-73.

295. See Gillette, supra note 235 , at $964-68$. 
York City. A significantly smaller percentage of its population is either in or near poverty, and a comparably smaller percentage receives public assistance. ${ }^{296}$ Its crime rate is well below that of the City as a whole. ${ }^{297}$ Being a part of New York City forces Staten Island, which in most demographic, economic, and social senses is far more like a suburb, to come to grips with urban problems.

The departure of Staten Island would also make New York City more homogeneous in certain ways. The City would lose many of its Republican elected officials and the only borough that frequently votes Republican in municipal elections. ${ }^{298}$ The City would also lose a noticeable chunk of its middle class and a strong voice for homeownership interests: with five percent of the City's residents, Staten Island has eighteen percent of the City's single-family owner-occupied dwellings. ${ }^{299}$ In effect, Staten Island brings a little of the suburb-and, perhaps, a little of the rest of the United States-into the great city. ${ }^{300}$

The separation of Staten Island from the other four boroughs might promote internal empathy within each resulting city, thereby making each municipality easier to run, and would expand the opportunities for and satisfactions of citizen participation in local govern-

296. See An Independent Staten Island: Fiscal Implications, in Remedies of a Proud Outcast, supra note 54, app. A at 18; Passell, supra note 275, at B1.

297. See Robert D. McFadden, New York Leads Big Cities in Robbery Rate, but Drops in Murder, N.Y. Times, Aug. 11, 1991, §1, at 28. In 1990, homicide rate on Staten Island was 7.7 per 100,000 residents, compared with 30.9 for the city as a whole. In the same year, the robbery rate of Staten Island was 2.7 per 1000 residents, compared with 13.7 for the city as a whole. The Staten Island rates for these two major crimes were less than half the rates in the next lowest crime borough, Queens. See id.

298. During the 1980s the only Republicans holding elected municipal office were Council members from Staten Island. In 1991, for the first time in more than a decade, voters in Manhattan and Queens also elected Republicans to the City Council. Still, two of the five Republican Council members are from Staten Island, see James C. McKinley, Jr., New York City Council Results Show Ripples of Change, N.Y. Times, Nov. 6, 1991, at B1. Moreover, the only borough-wide elected Republican official is the Staten Island borough president, see Green Book 1991-92, supra note 253, at 24-27.

In the 1989 mayoral election, Republican Rudolph Giuliani lost to Democrat David Dinkins by 47,000 votes out of a total of $1,815,000$ cast. Giuliani swept Staten Island by a margin of 67,000 votes. Green Book 1991-92, supra note 253, at 4. Giuliani fought the second closest mayoral election in the history of Greater New York. See Sam Roberts, The New York Vote: Almost Lost at the Wire, N.Y. Times, Nov. 9, 1989, at 1. Without Staten Island Dinkins' margin of victory would have been more than double what it was.

299. See 1990 New York Census Summary, supra note 12, at 244 (Table 10).

300. Population density figures nicely illustrate the nature of Staten Island as a community poised between city and suburb. The population density of New York City as a whole is 23,705.3 per square mile. In Manhattan that figure rises to 52,378.0 per square mile, but even in the relatively low-rise borough of Queens density is $17,839.1$ per square mile. In the adjacent suburban counties of Nassau and Westchester densities are $4,488.7$ and $2,020.9$, respectively. With a density of $6,467.2$, Staten Island falls between the rest of the City and the inner suburbs-although closer to the suburban than to the central city end of the continuum. See id. at 355, 361 (Table 16). 
ment-especially on Staten Island-but by the same token it would make each city somewhat narrower and probably more parochial in outlook.

True political and cultural pluralism is advanced not by the separation of different groups into distinct municipalities but through political structures that promote interaction and require mutual accommodation to different perspectives. As the New Jersey Supreme Court put it in applying its standard of "social detriment" when reviewing a petition for detachment,

[w]e would suggest that social detriment might be found in a community's being deprived of [the secessionists'] participation in the religious, civic, cultural, charitable and intellectual activities of the municipality; their meaningful interaction with other members of the community and their contribution to its prestige and social standing; the part they play in [the] general scheme of their municipality's social diversity; and, conceivably, the wholesome effect their presence has on racial integration. ${ }^{301}$

Beyond the general significance of a reorganization that would produce new and more homogeneous polities, features of this secession may be particularly troubling. First, at a time of highly charged racial tensions, ${ }^{302}$ secession would constitute a mass exodus of a predominantly white, middle class community from a jurisdiction marked by extremes of rich and poor and an emerging majority of people of color. Staten Island secessionists angrily bridle at any imputation of racist motivation, and insist that their movement is prompted by a mix of resentments over the City's use of Staten Island's land to locate undesirable facilities, the quality of local public services and the uses of their tax dollars, and a general interest in self-determination. ${ }^{303}$ But the broad socially demoralizing effects of white flight-and this would be white flight on a grand scale-go beyond the motives and intentions of individuals. Secession would be seen by many as one further instance of white, middle-class people choosing to separate themselves from poor, nonwhite people-the pattern characteristic of our metropolitan areas. This time, however, whites would not even have to undergo the inconvenience of moving to do so.

Second, the Staten Island secession is plainly a response to the Morris decision, ${ }^{304}$ yet Morris was simply a determination that the dem-

301. Ryan v. Mayor of Demarest, 319 A.2d 442, 449 (N.J. 1974).

302. See, e.g., Jim Sleeper, The Closest of Strangers: Liberalism and the Politics of Race In New York (1990); Jonathan Rieder, Canarsie: The Jews and Italians of Brooklyn Against Liberalism (1985).

303. See, e.g., John J. Marchi, Letter to the Editor, Marchi Responds on Secession Issue, N.Y. L.J., Apr. 24, 1991, at 2; John J. Marchi, Letter to the Editor, State Senator Disputes Article on Secession, N.Y. L.J., Feb. 13, 1991, at 2 [hereinafter Marchi February Letter].

304. See, e.g., Marchi February Letter, supra note 303, at 2. 
ocratic rule of "one person, one vote" ought to apply to Staten Islanders in their relations with the rest of New York City. As the Supreme Court has explained, equal representation for equal numbers of people is the one constitutional "ground rule" of American representative institutions. ${ }^{305}$ Staten Islanders are represented in City government, and their representation is exactly that to which their numbers entitle them. To claim as a "grievance" that it is no longer receiving extra representation may itself be an affront to democratic norms.

Staten Islanders justify their sense of unfairness at being subjected to the standard rule of representation based on population with the claim that they are a minority within the City-a literally "discrete and insular" one-and that they need the extra representation to protect their interests. Even though municipal deliberations are conducted according to democratic rules and are subject to the protections afforded fundamental rights, Staten Islanders fear that because of the differences between themselves and other New Yorkers they will be consistently disfavored by the outcomes of local politics. To return to the question of the proper "self" for local self-determination, ${ }^{306}$ Staten Islanders are asserting that they are a distinct group with distinct interests apart from those of other New Yorkers. If they cannot receive extra representation within New York City, then they say they need to have a separate local polity of their own.

The political participation argument for local autonomy has no answer to the question of whether a group that sees itself as a dissenting faction should stay in the old community or be allowed to break away and establish a new one. In the participationists' heady rhetoric, deliberation and debate lead to the resolution of conflict and the reconciliation of differences. In their model (like the economists'), there are no winners or losers, rather, everybody wins, and not much attention is paid to what happens when conflicts are not settled and differences not accommodated. ${ }^{307}$ There may, however, be groups within a political community that are consistently defeated even when the political process is played according to democratic rules. Would democratic values be better served if that jurisdiction is preserved as one polity or broken up? As noted in the discussion of the secession referendum franchise in Part II, there is no abstract standard within democratic theory for resolving this dilemma.

The most celebrated statement in our political culture concerning the relationship between secession and democracy was that put forward by Abraham Lincoln on the eve of the Civil War. According to Lincoln,

305. See Avery v. Midland County, 390 U.S. 474, 485 (1968).

306. See supra notes 126-134 and accompanying text.

307. This may be so because despite all the talk about the reconciliation of differences, participationists have a mental model of relatively homogeneous communities when they speak of local autonomy, so the question does not arise for them. 
secession is fundamentally at odds with democratic self-government based on majority rule; indeed,

the central idea of secession, is the essence of anarchy. A majority, held in restraint by constitutional checks, and limitations, and always changing easily, with deliberate changes of popular opinions and sentiments, is the only true sovereign of a free people. Whoever rejects it, does, of necessity, fly to anarchy or to despotism. Unanimity is impossible; the rule of a minority, as a permanent arrangement, is wholly inadmissible; so that, rejecting the majority principle, anarchy, or despotism in some form, is all that is left. 308

Lincoln's position is too strong. If democratic theory can yield no metric for determining the proper dimensions for a polity, it cannot preclude the possibility that some polities, riven by internal "irreconcilable differences," might be better off divided into separate new entities. Simply because the notion of a right to self-determination does not tell us which groups should have their own states, that does not mean that two groups might not be better off if separated into distinct states. The American Revolution was such a secession; ${ }^{309}$ as was the peaceful separation of Norway from Sweden. ${ }^{310}$ Lincoln himself played a role in the separation of the people of the mountainous part of Virginia-now known as West Virginia-from the rest of their state. ${ }^{311}$

It may be more accurate to modify Lincoln's statement and say instead that secession is a reflection of profound pessimism about the capacity of a polity to handle serious internal differences democratically and to govern all residents fairly. The call for a secession is a cry of despair from a minority about the capacity of majority rule to work for them. Authorization of secession by a higher level unit of government is tantamount to a conclusion that the economic, social, or demographic factors that separate the groups in a polity are so deep as to constitute unbridgeable chasms, precluding the empathy, mutual trust, and forbearance necessary to make one state work for all its people.

In a sense, this criticism is a variation on the theme of secession as an alteration of the status quo. Even if from a public choice or a participatory perspective both Staten Island and New York City would have been better off if they had never been joined, there can be real harms from the separation-the costs of disentangling shared public services and regulatory policies; the loss of middle class residents from the central city; the potential unfairness in the redistribution of public infrastructure; and the symbolic significance of a large group of people deciding that they cannot continue to govern themselves together even under democratic rules and procedures.

308. Lincoln, supra note 267 , at 220 .

309. See Buchanan, supra note 24 , at 24.

310 . See Jacobs, supra note 231 , at 26-51.

311. See James M. McPherson, Battle Cry of Freedom 297-304 (1988). 
To be hopeful about democracy is to disfavor secession and to require compelling evidence before concluding that one polity will not work for all its people. Secession should be predicated on a showing that the municipal majority is systematically exploiting the minority, or at the very least that the majority is advancing only its own values and consistently ignoring the minority's needs and interests. ${ }^{312}$ Lincoln notwithstanding, secession and democracy can coexist where such a showing is made.

In the case of Staten Island, the democratic presumption against secession ought to apply. Although the economic, political, and demographic differences between Staten Island and the other four boroughs have been underscored, those differences should not be exaggerated. It is far from clear that Staten Islanders are the sort of distinctive minority, let alone an exploited or abused one, for whom secession may be a necessary antidote for the possible inability of democracy to handle persistent and polarizing differences. Staten Island and New York City are not divided by language, religion, or historic ethnic or cultural conflicts. Indeed, as the rapid population growth of Staten Island in recent decades indicates, many adult Staten Islanders were not born on the Island but emigrated to it from one of the other four boroughs.

Of course, the standards of linguistic, religious, or longstanding cultural division typically used to consider the propriety of secession in the international arena may be a little excessive in debating the organization of local governments. Staten Island is not seeking a seat in the United Nations or the right to print its own currency, just municipal independence. It certainly does not have to show that it is as distinctive from New York City as Lithuania is from Russia or Quebec from the rest of Canada.

Nevertheless, even at the local level, the distinctiveness of Staten Islanders may be exaggerated. Although the Board of Estimate is gone, there does not appear to be anything in the City's political structure that would inhibit Staten Islanders' ability to make common cause with middle-class homeowners in the other "outer boroughs," particularly Brooklyn and Queens, with respect to tax and fiscal questions or the municipal services to be supported or opposed in the allocation of the City's resources. Indeed, middle-class outer-borough homeowners remain a potent force in the City's politics. ${ }^{313}$ Moreover, whatever the successes or failures of this group in the City's politics, there is no evidence that Staten Islanders are distinctively worse off than other middle-class homeowners. To authorize the secession of Staten Island on the grounds of some sort of economic or social distinctiveness could lead to the further disaggregation of the City on economic or social

312. See Buchanan, supra note 24 , at $38-45$ (defending secession when necessary to escape discriminatory redistribution).

313. See, e.g., Sam Roberts, The Budget Battles; The Twisting Road to a Budget Deal, N.Y. Times, July 2, 1991, at B5. 
lines. ${ }^{314}$

The more plausible argument for secession is site-specific exploitation; that is, the claim that because Staten Islanders are not just relatively small in numbers but also "discrete and insular"-or, rather, discrete because they are insular-the City is loading up their Island with locally undesirable land uses. Determining the justice of this argument is beyond the scope of this Article. However, it can be noted that, first, many other neighborhoods in the City, particularly minority communities, can and have made the same argument; ${ }^{315}$ and second, this argument tends to be one-sided, ignoring the City's creation and maintenance of facilities on Staten Island that benefit Staten Islanders. It may be that Staten Islanders can make out a case for land use exploitation, and that such exploitation would justify secession, but a clear and convincing case of site-specific exploitation should be required before secession is allowed. ${ }^{316}$

In the absence of such a showing, a hopeful commitment to democracy, like a concern for the loss of a central city tax base, militates against secession. Although secession might increase the possibilities for participatory democracy on Staten Island itself, secession would be a significant, albeit symbolic, pronouncement about the failure of democracy in a heterogeneous urban setting. The secession of Staten Island would be a statement that the diverse races, classes, and income groups that make up New York City and share in the City's economy and cultural institutions are unable to work together toward the common enterprise of regional self-government. It would be a statement that these differences within the City are sufficiently irreconcilable as to require such a municipal divorce. And that would be a very sad statement indeed.

\section{Beyond Secession: A Postscript}

Although the case for secession in terms of the "over-all public interest" of the New York metropolitan area is uncertain, there may be some lessons for New York City from the Staten Island secession movement and from the review of the theoretical literature on metropolitan governance. The strengths of a consolidated government like Greater New York's is its capacity to provide area-wide functions and to call upon a broad, five-borough tax base to serve the needs of all City residents. Its weaknesses, as the public choice and political participation

314. The Staten Island secession movernent has inspired a secession effort on behalf of New York's largest middle-class borough, Queens. See Kevin Sack, State Senate Passes Bill to Allow Queens to Begin Secession Effort, N.Y. Times, Apr. 29, 1992 , at B4.

315. See, e.g., Jill Weiner, A Toilet Bowl Is in Our Backyard, N.Y. Newsday, Jan. 15, 1992, at 79 (interview with Peggy Shepard).

316. Cf. Buchanan, supra note 24 , at 38-45 (justifying secession when necessary to escape discriminatory redistribution). 
critiques suggest, are its lack of both accountability for delivery of local services and popular participation in governance.

Staten Island's complaints about the costs and quality of local public services, municipal land use and siting decisions, and insufficient attention from City Hall are shared by many other City neighborhoods. Indeed, Staten Island's small population, determinate borders, and historical identity suggest not that it is more likely to be exploited, but rather that is easier for Staten Islanders to organize and articulate the kinds of community concerns generic for most New Yorkers. ${ }^{317}$ The intense disaffection with the cost, ineffectiveness, and insensitivity of the City's government that the secession movement has revealed on Staten Island is no doubt shared by many other areas on the City.

Rather than simply either ignore secession or move to block it in the legislature or in the courts, ${ }^{318}$ the City should take seriously the message behind the secession movement and begin to consider possible ways to restructure its government to decrease the central municipal bureaucracy, increase the role of neighborhoods in planning ${ }^{319}$ and overseeing the delivery of public services, and promote substantive fairness in the siting of locally undesirable land uses. ${ }^{320}$

Although the Morris decision precludes the form of municipal federalism that would give local subunits more representation in City government than "one person, one vote," would allow, there is nothing to prevent, and much to encourage the use of subunit lines for the decentralization of service delivery and community participation in planning and public decision-making. The City could continue to utilize the fis-

317. See generally Mancur Olson, The Logic of Collective Action: Public Goods and the Theory of Groups 53 (1965) (showing "the greater effectiveness of small groups"); Bruce A. Ackerman, Beyond Carolene Products, 98 Harv. L. Rev. 713, 727 (1985) (arguing that sociologically diffuse groups are less successful than non-diffuse groups).

318. The success of the secession measure in the legislature in 1989 and 1990 raises questions about the City's ability ultimately to block secession enabling legislation through legislative lobbying. Indeed, since secession would return to the legislature only after the Staten Island electorate has voted to separate from New York City, the rhetoric of local popular self-determination could give secession very powerful momentum. As for judicial protection, the ultimate significance of the Court of Appeals' decision in the Secession Referendum case is difficult to divine. Although two members of the court were willing to block ever the initial secession referendum on home rule grounds, and the court majority avoided any clear pronouncement on the home rule question, see supra text accompanying notes 190-192, the home rule case law counsels against any certainty that the court would invalidate a secession enabling law.

319. One step in this direction is section 197-a of the new City Charter, which permits boroughs and communities to initiate their own plans for land use development and growth and requires the City Planning Commission to develop rules for the provision of the technical assistance necessary for such plans to satisfy state and local environmental impact analysis. See 1990 N.Y. Laws 34, ch. 17, § 197-a.

320. This is the intent of sections 203 and 204 of the new City Charter, which require the development and utilization of "fair share" criteria for the location of city facilities. See 1990 N.Y. Laws 35, chap. 17, §§ 203-204. 
cal resources of the City as a whole and maintain City-wide political institutions for the deliberation of City-wide policy questions and resource allocations, but subunits could be used as focal points for greater public involvement, enhanced government accountability, and improved service performance. Such structural changes could realize some of the economic and political benefits of a secession while preserving the City's tax base, avoiding the negative redistribution that secession would occasion, and symbolizing the potential of selfgovernment to work, even in the most complex, heterogenous, and conflict-ridden urban setting. 